Prepared in cooperation with the New York State Department of Environmental Conservation

Time-Domain Electromagnetic Soundings and Passive-Seismic Measurements for Delineation of Saline Groundwater in the Genesee Valley-Fill Aquifer System, Western New York, 2016-17

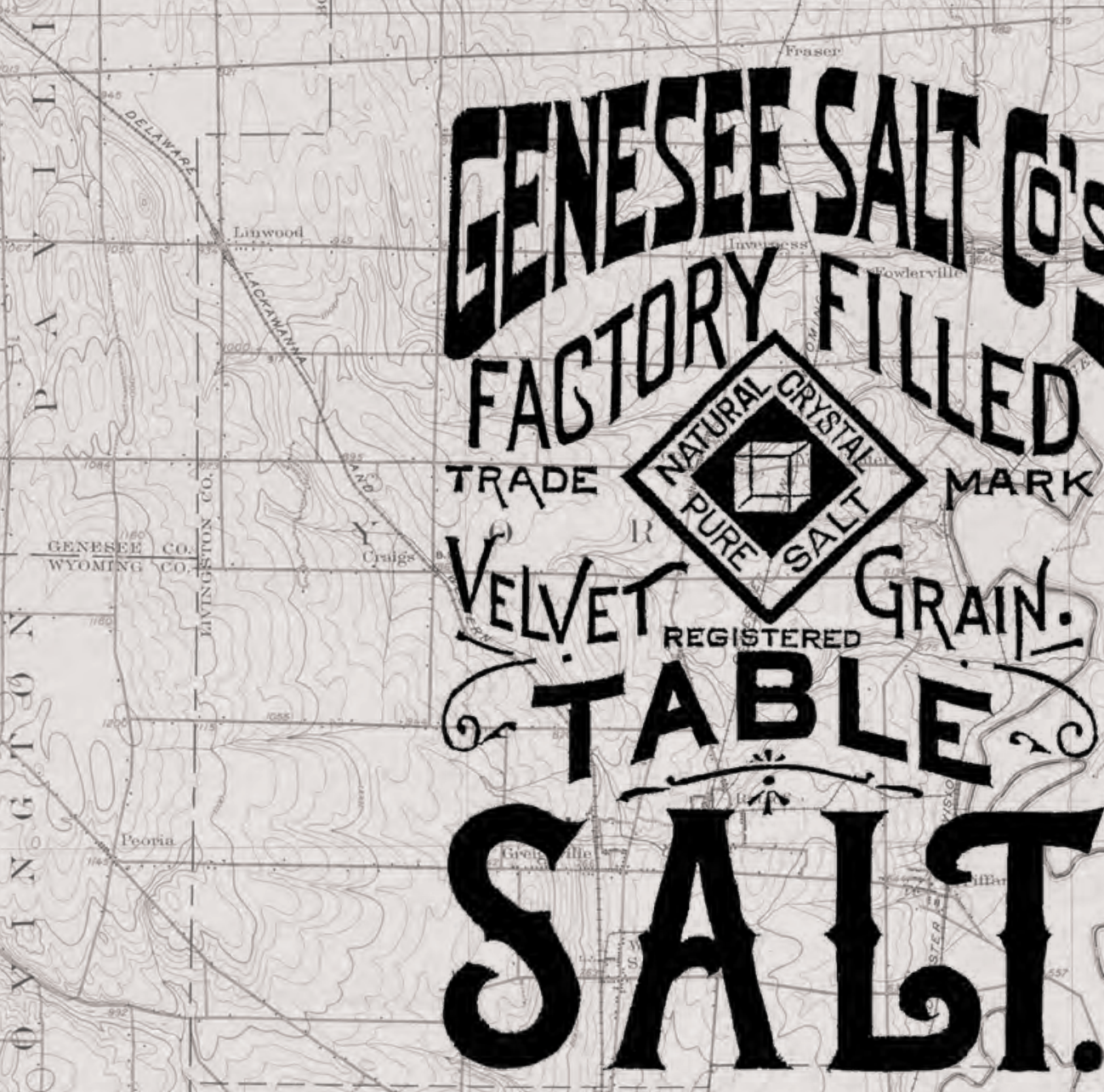

Scientific Investigations Report 2021-5008 
Front cover. Topographic map of Genesee Valley, New York, with an antique logo taken from a table salt sales brochure of the Genesee Salt Company, originally located in Piffard, New York.

Back cover. From the same brochure, the company pitches seven benefits of its product. 


\section{Time-Domain Electromagnetic Soundings and Passive-Seismic Measurements for Delineation of Saline Groundwater in the Genesee Valley-Fill Aquifer System, Western New York, 2016-17}

By John H. Williams, William M. Kappel, Carole D. Johnson, Eric A. White, Paul M. Heisig, and John W. Lane, Jr.

Prepared in cooperation with the

New York State Department of Environmental Conservation

Scientific Investigations Report 2021-5008 


\section{U.S. Geological Survey, Reston, Virginia: 2021}

For more information on the USGS — the Federal source for science about the Earth, its natural and living resources, natural hazards, and the environment—visit https://www.usgs.gov or call 1-888-ASK-USGS.

For an overview of USGS information products, including maps, imagery, and publications, visit https://store.usgs.gov/.

Any use of trade, firm, or product names is for descriptive purposes only and does not imply endorsement by the U.S. Government.

Although this information product, for the most part, is in the public domain, it also may contain copyrighted material and images protected by publicity rights. Use of photographs or images may require permission to reproduce copyrighted items or the likeness of a person. Permission must be secured from the copyright owner or person whose likeness is being used. For more information, visit https://usgs.gov/copyright.

Suggested citation:

Williams, J.H., Kappel, W.M., Johnson, C.D., White, E.A., Heisig, P.M., and Lane, J.W., Jr., 2021, Time-domain electromagnetic soundings and passive-seismic measurements for delineation of saline groundwater in the Genesee valley-fill aquifer system, western New York, 2016-17: U.S. Geological Survey Scientific Investigations Report 2021-5008, 25 p., https://doi.org/10.3133/sir20215008.

Associated data for this publication:

Heisig, P.M., Williams, J.H., Johnson, C.D., White, E.A., and Kappel, W.M., 2021, Horizontal-to-vertical spectral ratio and depth-to-bedrock data for saline-groundwater investigation in the Genesee valley, New York, OctoberNovember 2016 and 2017: U.S. Geological Survey data release, https://doi.org/10.5066/PGLI7CCR.

Kappel, W.M., and Williams, J.H., 2021, Chloride concentrations from wells in the Genesee River Valley, Livingston County, New York: U.S. Geological Survey data release, https://doi.org/10.5066/P9J354SU.

White, E.A., Johnson, C.D., Williams, J.H., and Kappel, W.M., 2021, Time-domain electromagnetic soundings to delineate saline groundwater in the Genesee valley-fill aquifer system, New York (2016-2017): U.S. Geological Survey data release, https://doi.org/10.5066/P9V00CRZ.

ISSN 2328-0328 (online) 


\section{Acknowledgments}

The authors thank the farmers and landowners of the Genesee River Valley for graciously granting access to their fields and property to collect the geophysical soundings that support this project. Without their cooperation, this study would not have been possible. The authors also thank Robert Stryker of the Livingston County Soil and Water Conservation District who helped coordinate land access with the farming community. The able support of Alton Anderson, Adam Baldwin, Mike Izdebski, Katt Pappas, and Katherine Swager of the U.S. Geological Survey during field-data collection are greatly appreciated. 



\section{Contents}

Acknowledgments ……...................................................................................................................

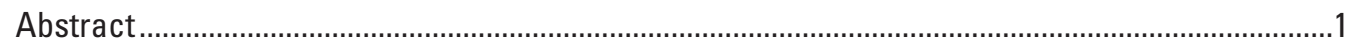

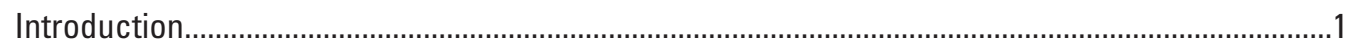

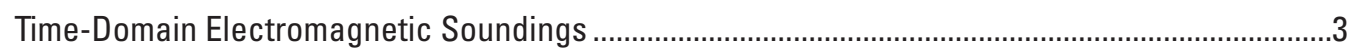

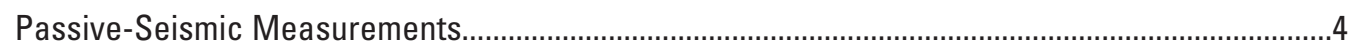

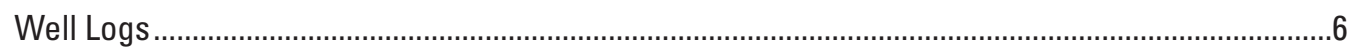

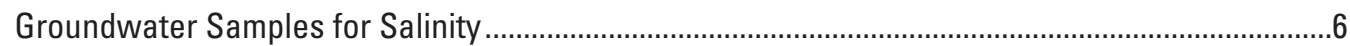

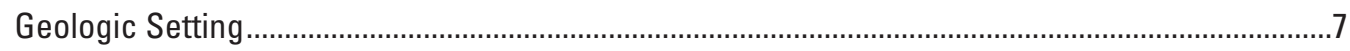

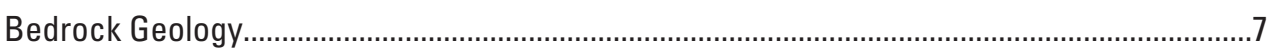

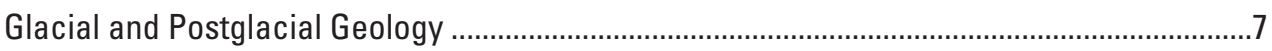

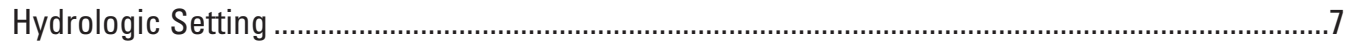

Aquifer and Confining Units ...................................................................................................

Groundwater Flow ..................................................................................................................

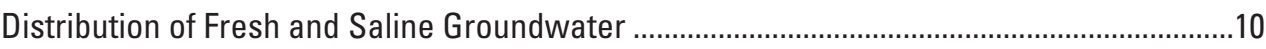

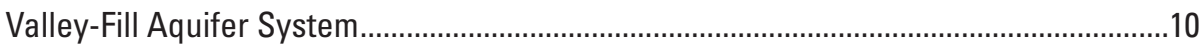

Onondaga and Bertie Limestones................................................................................12

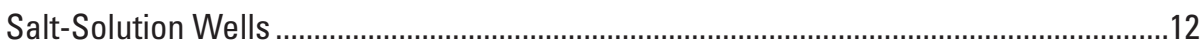

Syracuse D Salt and Brine Pools ...........................................................................13

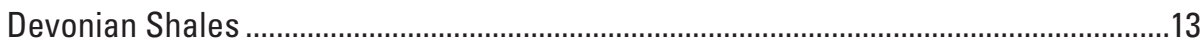

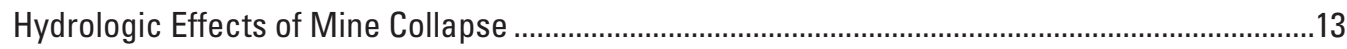

Mine Collapse, Rubble Chimneys, and Flooding ..............................................................

Groundwater-Level Decline and Salinity Increase ...........................................................16

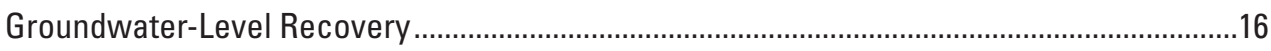

Upward Flow of Saline Water Through Rubble Chimneys.....................................................16

Remedial Pumping to Mitigate Saline-Water Migration ...........................................................16

Delineation of Saline Groundwater in the Valley-Fill Aquifer System..............................................20

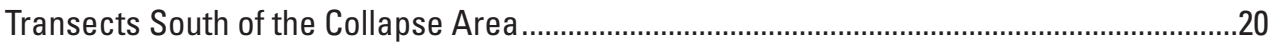

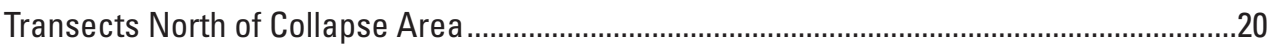

Transects East of Piffard.........................................................................................................22

Fowlerville Moraine Transects .............................................................................................23

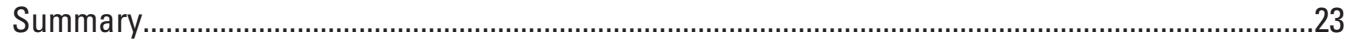

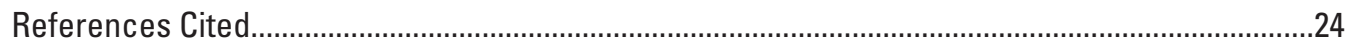

\section{Figures}

1. Surficial geology of the study area, location of the former Retsof salt mine, and associated features in the Genesee River Valley in western New York ............................2

2. Schematic of the time-domain electromagnetic equipment and the transmission and reception of electromagnetic signals.

3. Graph of peak-resonance frequencies from passive-seismic measurements with reported depths to bedrock at wells in the Genesee River Valley in western New York 
4. Generalized geologic section across the Genesee River Valley in western New York .8

5. Generalized geologic section along the axis of the Genesee River Valley in western New York; modified from Yager and others (2001). .9

6. Generalized hydrogeologic section across the Genesee River Valley in western New York; modified from Yager and others (2001)

7. Map of distribution of the Syracuse D salt and brine pools in the Genesee River Valley in western New York.

8. Logs of lithostratigraphy, chloride concentration, electrical conductivity, and the results of a time-domain electromagnetic sounding from sites in the Genesee River Valley in western New York.

9. Generalized hydrogeologic section across the Genesee River Valley in western New York, following the development of a rubble chimney, surface sinkhole, and flooding into the mine.

10. Map of land subsidence, water-level drawdowns, and wells in which water levels declined, became saline, or produced gas after the mine collapse

11. Generalized hydrogeologic section along the axis of the Genesee River Valley in western New York during mine flooding, with southward movement of saline groundwater from the Bertie Limestone during mine flooding.

12. Generalized hydrogeologic section across the Genesee River Valley in western New York, showing upward flow of saline water through the rubble chimneys and into the lower confined aquifer after complete mine flooding and aquifer recovery

13. Graphs of chloride concentrations in groundwater sampled from wells in the Genesee River Valley in western New York from 2006 to 2014

14. Logs of lithostratigraphy, natural gamma, electromagnetic-conductivity, and chloride concentrations, and time-domain electromagnetic soundings from sites in the Genesee River Valley in western New York.

15. Lithostratigraphy and gamma and electromagnetic-conductivity logs from 1994 from borehole Lv345 in the Genesee River Valley in western New York...

\section{Table}

1. Site identification and well logs, chloride samples, and passive-seismic measurements available for selected wells in the Genesee River Valley in western New York

\section{Plate}

1. Electrical-conductivity transects from time-domain electromagnetic soundings, top of bedrock estimated from passive-seismic measurements, and lithostratigraphic logs of selected boreholes along 13 transects in the Genesee River Valley, western New York, 2016-17 


\section{Conversion Factors}

U.S. customary units to International System of Units

\begin{tabular}{lcl}
\hline \multicolumn{1}{c}{ Multiply } & By & \multicolumn{1}{c}{ To obtain } \\
\hline inch (in.) & 25.4 & millimeter $(\mathrm{mm})$ \\
foot (ft) & 0.3048 & meter $(\mathrm{m})$ \\
mile (mi) & 1.609 & kilometer $(\mathrm{km})$ \\
gallon per minute (gal $/ \mathrm{min})$ & 3.785 & liter per minute $(\mathrm{L} / \mathrm{min})$ \\
\hline
\end{tabular}

\section{Datum}

Vertical coordinate information is referenced to the North American Vertical Datum of 1988 (NAVD 88).

Horizontal coordinate information is referenced to the North American Datum of 1983 (NAD 83).

Altitude, as used in this report, refers to distance above the vertical datum.

\section{Supplemental Information}

Specific conductance is given in microsiemens per centimeter at 25 degrees Celsius $(\mu \mathrm{S} / \mathrm{cm}$ at $\left.25^{\circ} \mathrm{C}\right)$.

Concentrations of chemical constituents in water are given in milligrams per liter (mg/L).

\section{Abbreviations}

Akzo Akzo Nobel Salt Inc. (former owner of the Retsof mine)

bls below land surface

TDEM time-domain electromagnetic

USGS U.S. Geological Survey 



\title{
Time-Domain Electromagnetic Soundings and Passive-Seismic Measurements for Delineation of Saline Groundwater in the Genesee Valley-Fill Aquifer System, Western New York, 2016-17
}

\author{
By John H. Williams, William M. Kappel, Carole D. Johnson, Eric A. White, Paul M. Heisig, and \\ John W. Lane, Jr.
}

\section{Abstract}

The U.S. Geological Survey, in cooperation with the New York State Department of Environmental Conservation, used noninvasive surface geophysics in the investigation of the distribution of saline groundwater in the valley-fill aquifer system of the Genesee River Valley near the former Retsof salt mine in western New York. In 1994, the Retsof salt mine, the largest of its kind in the western hemisphere, underwent a catastrophic roof collapse that resulted in groundwater inflow from the valley-fill aquifer system and bedrock fracture zones into the mine through two bedrock-rubble chimneys and the subsequent dissolution and filling of the mine with saturated brine. Since the early 2000 s, except for a period of remedial pumping in 2006 to 2013, high-salinity water has migrated upward through the rubble chimneys into the basal part the aquifer system. The extent of saline-water migration within the aquifer system had not been evaluated since the end of remedial pumping when all the monitoring wells were grouted shut and abandoned. Installation of a monitoring-well network would be expensive and difficult given the thickness and heterogeneous character of valley fill. An investigation of the current extent of saline water in the aquifer system was warranted because the basal part of the aquifer is shallow to the north and it is used for water supply.

In fall 2016 and fall 2017, the U.S. Geological Survey collected time-domain electromagnetic soundings at 105 sites along 13 cross-valley transects north and south of the minecollapse area, east of Piffard, and on the Fowlerville Moraine. The time-domain electromagnetic soundings were colocated with passive-seismic measurements to estimate the bedrocksurface elevation through use of a regression equation developed from measurements at well sites with reported bedrock depths in the study area. An integrated analysis of the timedomain electromagnetic soundings with the depth-to-bedrock estimates, well logs, and past chloride-monitoring data suggests the presence of a zone of high electrical conductivity associated with saline water in the confined lower part of the valley-fill aquifer system. This high-salinity zone delineated in the lower confined aquifer extends from the mine-collapse area northward for more than 2.5 miles (4.0 kilometers). The chloride concentration in groundwater within this highconductivity zone may be about 20,000 milligrams per liter. Saline water flowing upward through the bedrock-rubble chimneys and mixing with northward groundwater flow in the lower confined aquifer likely is a major source of chlorides for this high-conductivity zone. The northern extent of the zone is unclear because of the presence of highly saline water zones that were delineated by time-domain electromagnetic soundings in the lower confined aquifer and uppermost bedrock and are probably associated with historic salt-solution wells in Piffard or possibly sourced from natural brine pools.

\section{Introduction}

The U.S. Geological Survey (USGS), in cooperation with the New York State Department of Environmental Conservation, used time-domain electromagnetic (TDEM) and passive-seismic methods in the investigation of the distribution of saline water in the valley-fill aquifer system of the Genesee River Valley near the former Retsof salt mine in western New York (formerly owned by Akzo Nobel Salt Inc. [Akzo]; fig. 1). In 1994, the Retsof salt mine, the largest of its kind in the western hemisphere, underwent a catastrophic roof collapse that resulted in groundwater inflow from the aquifer system into the mine through two bedrock-rubble chimneys. Since the early 2000 s, except for a period of remedial pumping from 2006 to 2013, high-salinity water has migrated upward through the rock-rubble chimneys and into the basal part of the aquifer system. The extent of saline-water migration in the aquifer system had not been evaluated since the end of remedial pumping when all the monitoring wells were plugged and abandoned. An investigation of the current extent 


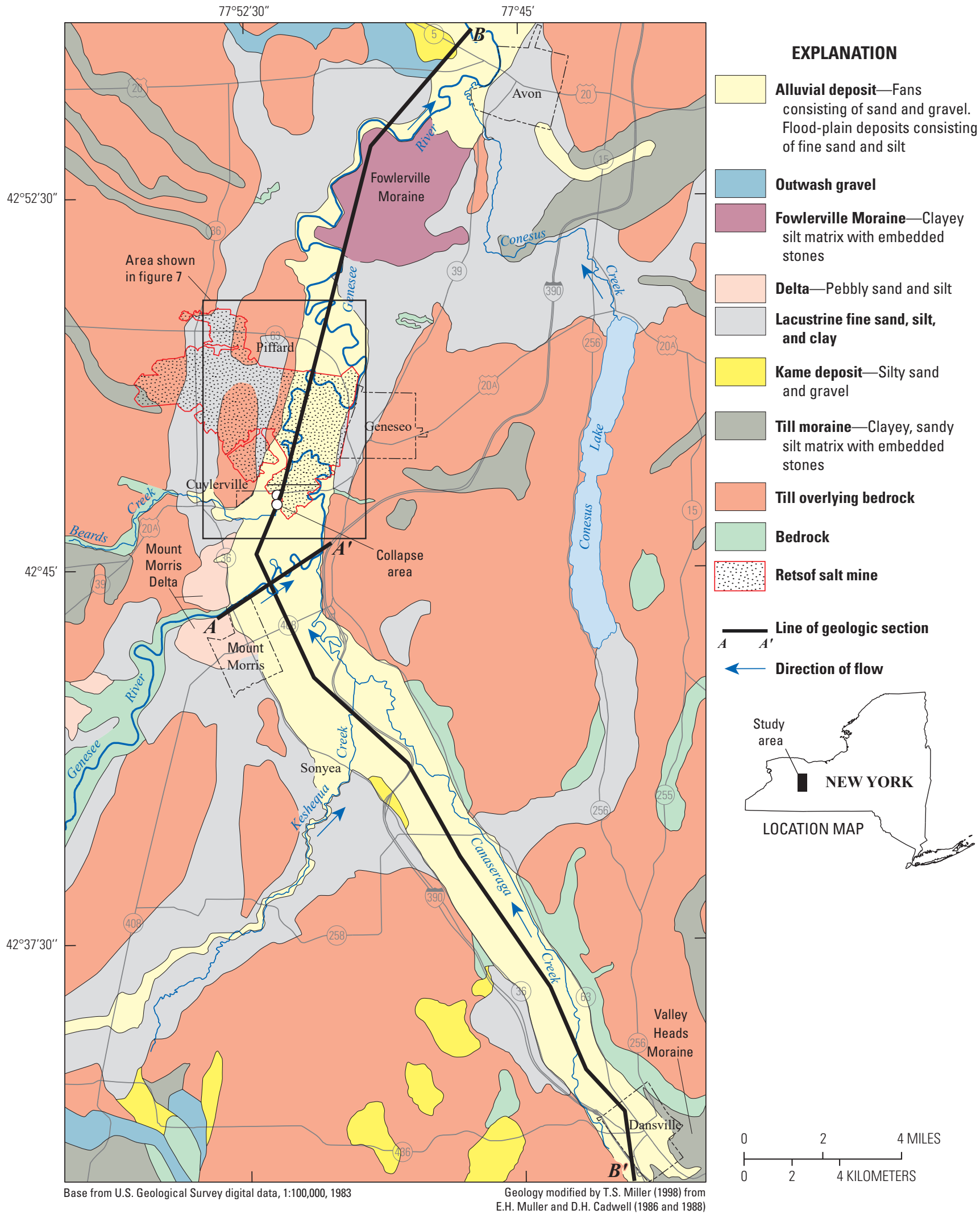

Figure 1. Surficial geology of the study area, location of the former Retsof salt mine, and associated features in the Genesee River Valley in western New York; modified from Yager and others (2001). 
of saline water in the aquifer system was warranted because the depth to bedrock and the thickness of the basal valley fill decrease to the north where the water is used for public supply.

This report describes the application of the time-domain electromagnetic and passive-seismic methods and presents an integrated analysis of results from those methods with data from well $\log$ and chloride-concentration monitoring to delineate zones of high electrical conductivity associated with saline water in the valley-fill aquifer during 2016-17. The electrical conductivity of the valley fill and underlying bedrock were measured along cross-valley transects from 1.5 miles (mi; 2.4 kilometers [km]) south to $8 \mathrm{mi}(13 \mathrm{~km})$ north of the collapsed mine (fig. 1).

\section{Time-Domain Electromagnetic Soundings}

TDEM soundings and passive-seismic measurements were analyzed by using well logs and groundwater-sample data from previous investigations to delineate subsurface zones of high electrical conductivity associated with saline groundwater in the lower part of the valley fill and the underlying bedrock. The TDEM sounding method uses a transmitter to drive an electrical current through a square loop of insulated cable on the ground and a receiver to measure the current induced in the subsurface (fig. 2). The current has equal on-and-off time periods and base frequencies that generally range from 30 to 300 hertz $(\mathrm{Hz})$. Termination of the current flow is not instantaneous but occurs over a very brief period (a few microseconds) known as the ramp time, during which the magnetic field varies. The time-variant nature of the primary electromagnetic field creates a secondary electromagnetic field in the ground beneath the loop that, in accordance with Faraday's law, generally mirrors the transmitter loop (Christiansen and others, 2006). This secondary field immediately begins to decay, generating additional eddy currents that propagate downward and outward into the subsurface like a series of smoke rings.

Measurements of the secondary currents are made during the time-off period by one or more receivers located in the center of the transmitter loop. The signal strength of the decaying currents at specific times and depths is controlled by the bulk conductivity of the subsurface, which includes the conductivity of subsurface rock and sediment units and their contained fluids (Stewart and Gay, 1986; McNeill, 1994; Auken and others, 2008). The subsurface conductivity is estimated from the voltage-decay curve collected at the receiver through an inversion process described below. The depth of investigation depends on the time interval after shutoff of the current and the signal strength of the late-time signal; at later times, the receiver is sensing eddy currents at progressively greater depths. At early times, the receiver senses shallow depths; hence, shorter reception-time periods are required for the resolution of shallow layers. In addition to the equipment's ability to monitor the early and late times of the transient signal, the factors that control the depth of investigation include the initial magnitude of the magnetic moment (proportional to the size of the loop and the current), the attenuation of the signal by the resistivity of the subsurface, and the background noise.

TDEM sounding data were collected at 105 sites along 13 transects in the Genesee River Valley north and south of the mine-collapse area (pl. 1). In fall 2016, TDEM data were collected at 40 sites along 7 transects. In fall 2017, TDEM data were collected at an additional 65 sites to complete measurements along 6 of the 2016 transects, and to establish 6 new transects; also, TDEM data collection was repeated at 10 of the 2016 sites. The TDEM data were collected by using ABEM WalkTEM units with a 40 -by 40 - or 100 - by 100 -meter (m)-square transmitter loop and $0.5-$ by $0.5-\mathrm{m}$ and 10 - by 10 -m-square center-loop receivers. The 100 - by 100 -m-square loop configuration was used for the 2016 soundings, and the 40- by 40-m-square loop configuration was used for the 2017 soundings. The dual-moment surveys use a low moment (and a low current of about 2 amperes) for early-time shallow measurements and a high moment (about 15-A current) for latetime deep measurements. The voltage decay of the induced field was measured with two receivers, resulting in four sets of measurement data at the same site (high moment from both receivers, low moment from both receivers). TDEM data collection at several 2016 sites was repeated in 2017 with different WalkTEM units and loop configurations to ensure that the two datasets provided consistent results for the investigation target and could be combined into a single group of data for the purposes of the study.

The relation between the TDEM voltage-decay curve recorded at the receivers and the subsurface conductivity was determined by the use of Aarhus HydroGeophysics Group SPIA software and methods described by Auken and others (2015). The data at each site were filtered to identify and remove background noise caused by the measurement electronics or environmental sources. For all TDEM surveys, the following steps were taken to mitigate noise: (1) removal of early-time noise; (2) application of a standard-deviation threshold to data at each time gate and removal of data points that exceed that threshold; and (3) identification of the background noise and removal of all late-time decay before encountering the noise floor. For each sounding, data from both magnetic moments (caused by low current and high current) and both receivers were combined and inverted together.

The TDEM decay data were inverted without constraint by using both smooth- and layered-model approaches to generate resistivity models of the subsurface. The smooth models have multiple (approximately 20) layers with fixed thicknesses that change gradually, whereas the layered models have fewer layers with blocky or stepped transitions between the layers. Resistivity units were converted to conductivity units by use of the equation: 


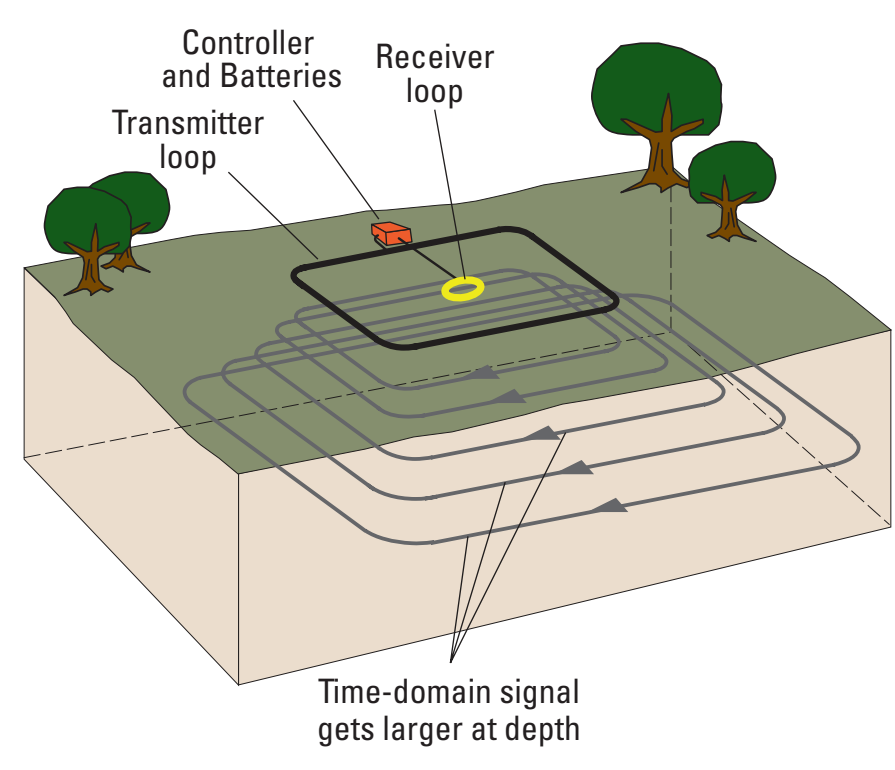

Figure 2. Features of the time-domain electromagnetic equipment and characterization of the transmission and reception of electromagnetic signals; modified from Payne and Teeple (2011). Time domain signals are sent down and received back from various depths.

$$
\sigma=\frac{1}{\rho} \times 1,000
$$

where

$\sigma \quad$ is conductivity, in millisiemens per meter; and $\rho \quad$ is resistivity, in ohm-meters.

The conductivity of a sand-and-water mixture as measured by the TDEM method is related to the conductivity of the water by the empirical relation described by Archie (1942) and presented by McNeill (1980) as follows:

$$
\frac{\sigma_{\chi}}{\sigma_{\omega}}=n^{m}
$$

where

$$
\begin{array}{cc}
\sigma \chi & \text { is the conductivity of the sand-and-water } \\
\text { mixture, in millisiemens per meter; } \\
\sigma \omega & \text { is the conductivity of water, in millisiemens } \\
\text { per meter; }
\end{array}
$$

The depth of investigation of the TDEM soundings were determined by using methods described by Christiansen and Auken (2012). The TDEM-soundings results were visualized in two-dimensional profiles created by use of the Aarhaus Workbench software. The TDEM-sounding locational information, raw data, and inversions are available from White and others (2021).

\section{Passive-Seismic Measurements}

The horizontal-to-vertical spectral ratio ambient-noise seismic technique (commonly referred to as the passiveseismic method) is used to estimate the thickness of unconsolidated sediments and the depth to bedrock (Nakamura, 1989). The passive-seismic method uses a single, broad-band three-component (two horizontal and one vertical) seismometer to record ambient seismic noise. In areas that have a strong acoustic contrast between the bedrock and overlying sediments, the seismic noise induces resonance at frequencies that range from about 0.3 to $40 \mathrm{~Hz}$. The ratio of the average horizontal-to-vertical spectrums produces a spectral-ratio curve with peaks at fundamental and higher-order resonance frequencies. The spectral-ratio curve (the ratio of the averaged horizontal-to-vertical component spectrums) is used to determine the fundamental resonance frequency that can be used with an average shear-wave velocity or a power-law regression equation to estimate sediment thickness and depth to bedrock (Lane and others, 2008; Brown and others, 2013; Chandler and Lively, 2014; Johnson and Lane, 2016).

The passive-seismic measurements were colocated with the 105 TDEM sounding sites (pl. 1). Passive-seismic measurements were collected at or near 13 well sites with reported depths to bedrock (table 1). The horizontal-to-vertical spectral ratio data were collected for 30 minutes at each site by using Tromino Model TEP-3C three-component seismometers. The horizontal-to-vertical spectral ratio data were processed with Tromino Grilla software to remove anthropogenic noise, convert the time-domain data to frequency domain, compute and plot the spectral-ratio curve, and determine the resonance frequency.

The resonance-frequency peaks for the passive-seismic measurements collected near well sites with reported depths to bedrock were used to develop a regression equation to estimate the depth to bedrock at the other measurement sites. A power-law regression equation was derived for the study area by using measurements at 12 well locations with known depths to bedrock (fig. 3; table 1). The passive-seismic measurement at well Lv340, which penetrated more than 80 feet (ft; 24 meters [m]) of very dense till (presumably with a greater shear-wave velocity than that in the more typical valley-fill sediments), was not used in the regression. The regression, which has a coefficient of determination $\left(R^{2}\right)$ of 0.9379 , relates the resonance frequency $(f r)$ to the depth to bedrock $(Z)$, in feet, as follows:

$$
Z=367.42 f_{r}^{-1.084}
$$

The local regression equation was used to estimate depth to bedrock at all other sites where the resonance frequency had been determined. Estimated depths to bedrock determined from the equation generally were within 10 percent of the reported depths to bedrock at the 12 control locations. The passive-seismic-measurement location information, 
Table 1. Site identification and well logs, chloride samples, and passive-seismic measurements available for selected wells in the Genesee River Valley in western New York.

[Well locations shown on plate 1. Lv302 indicates Livingston County well number assigned by the U.S. Geological Survey (USGS). Akzo, Akzo Nobel Salt Inc. (Retsof) mine; no., number; ID, identification number; X, available data; - , data not available; T, time-series samples available from 2004 to 2015; M, miscellaneous chloride samples available on various dates]

\begin{tabular}{|c|c|c|c|c|c|c|c|}
\hline $\begin{array}{l}\text { USGS local } \\
\text { well no. }\end{array}$ & $\begin{array}{c}\text { Akzo } \\
\text { well } \\
\text { no. } \\
\end{array}$ & USGS site ID & Geologist ${ }^{1}$ & Gamma $^{2}$ & $\begin{array}{l}\text { Resistivity/ } \\
\text { conductivty }\end{array}$ & $\begin{array}{c}\text { Chloride } \\
\text { sample }^{3}\end{array}$ & $\begin{array}{l}\text { Passive } \\
\text { seismic }^{4}\end{array}$ \\
\hline Lv302 & 9402 & 424658077505301 & $\mathrm{X}$ & $\mathrm{X}^{5}$ & - & - & - \\
\hline Lv309 & 9409 & 424629077513701 & $\mathrm{X}$ & $X^{6}$ & $X^{6}$ & $\mathrm{~T}$ & - \\
\hline Lv322 & 9422 & 424637077513501 & $\mathrm{X}$ & $\mathrm{X}^{7}$ & - & $\mathrm{T}$ & - \\
\hline Lv334 & 9901 & 425202077490301 & $\mathrm{X}$ & - & - & M & $\mathrm{X}$ \\
\hline Lv335 & 9902 & 425030077494601 & $\mathrm{X}$ & - & - & M & $\mathrm{X}$ \\
\hline Lv336 & 9903 & 425112077491801 & $\mathrm{X}$ & - & - & M & $\mathrm{X}$ \\
\hline Lv340 & 9440 & 424907077510501 & $\mathrm{X}$ & $\mathrm{X}^{8}$ & $\mathrm{X}^{9}$ & M & $\mathrm{X}$ \\
\hline Lv345 & 9445 & 424719077512801 & $\mathrm{X}$ & $\mathrm{X}^{10}$ & $\mathrm{X}^{11}$ & - & - \\
\hline Lv346 & 9446 & 424626077515102 & $\mathrm{X}$ & $\mathrm{X}^{12}$ & - & $\mathrm{T}$ & $\mathrm{X}$ \\
\hline Lv349 & 9449 & 424528077510201 & $\mathrm{X}$ & $\mathrm{X}^{13}$ & - & M & - \\
\hline Lv350 & 9450 & 424528077510202 & - & - & - & M & $\mathrm{X}$ \\
\hline Lv351 & 9451 & 424528077510203 & - & - & - & M & - \\
\hline Lv360 & 9460 & 424521077521401 & $\mathrm{X}$ & - & - & M & $\mathrm{X}$ \\
\hline Lv368 & 9568 & 424626077515103 & $\mathrm{X}$ & - & - & $\mathrm{T}$ & - \\
\hline Lv397 & 7901 & 424743077505102 & - & - & $\mathrm{X}^{14}$ & M & $\mathrm{X}$ \\
\hline Lv421 & 21 & 425000077505001 & - & - & - & M & - \\
\hline Lv530 & 0405 & 424623077512501 & $\mathrm{X}$ & - & - & $\mathrm{T}$ & $\mathrm{X}$ \\
\hline Lv531 & 0501 & 424624077512501 & $\mathrm{X}$ & - & - & $\mathrm{T}$ & - \\
\hline Lv532 & 0502 & 424655077512501 & $\mathrm{X}$ & - & - & $\mathrm{T}$ & $\mathrm{X}$ \\
\hline Lv533 & 0503 & 424643077513001 & $\mathrm{X}$ & - & - & $\mathrm{T}$ & $\mathrm{X}$ \\
\hline Lv535 & 0505 & 424558077513802 & $\mathrm{X}$ & - & - & $\mathrm{T}$ & $\mathrm{X}$ \\
\hline Lv536 & 0506 & 424626077521401 & $\mathrm{X}$ & - & - & - & $\mathrm{X}$ \\
\hline
\end{tabular}

${ }^{1}$ Logs available from Empire State Organized Geologic Information System (New York State Department of Environmental Conservation, 2019) by searching on Akzo well number.

2Logs downloaded in log ASCII standard format from USGS GeoLog Locator (U.S. Geological Survey, 2019).

${ }^{3}$ Chloride sample data available from Kappel and Williams (2021).

4Passive-seismic measurement at or near well site available from Heisig and others (2021).

5Log available at https://txdata.usgs.gov/GeoLogArchiver/odata/Logs(26833)/LogFile.

${ }^{6} \mathrm{Log}$ available at https://txdata.usgs.gov/GeoLogArchiver/odata/Logs(18643)/LogFile.

${ }^{7}$ Log available at https://txdata.usgs.gov/GeoLogArchiver/odata/Logs(18655)/LogFile.

${ }^{8}$ Log available at https://txdata.usgs.gov/GeoLogArchiver/odata/Logs(18654)/LogFile.

${ }^{9}$ Log available at https://txdata.usgs.gov/GeoLogArchiver/odata/Logs(18653)/LogFile.

${ }^{10} \log$ available at https://txdata.usgs.gov/GeoLogArchiver/odata/Logs(26835)/LogFile.

${ }^{11} \log$ available at https://txdata.usgs.gov/GeoLogArchiver/odata/Logs(26836)/LogFile.

${ }^{12} \log$ available at https://txdata.usgs.gov/GeoLogArchiver/odata/Logs(26834)/LogFile.

${ }^{13} \log$ available at https://txdata.usgs.gov/GeoLogArchiver/odata/Logs(18651)/LogFile.

${ }^{14} \log$ available at https://txdata.usgs.gov/GeoLogArchiver/odata/Logs(18646)/LogFile. 


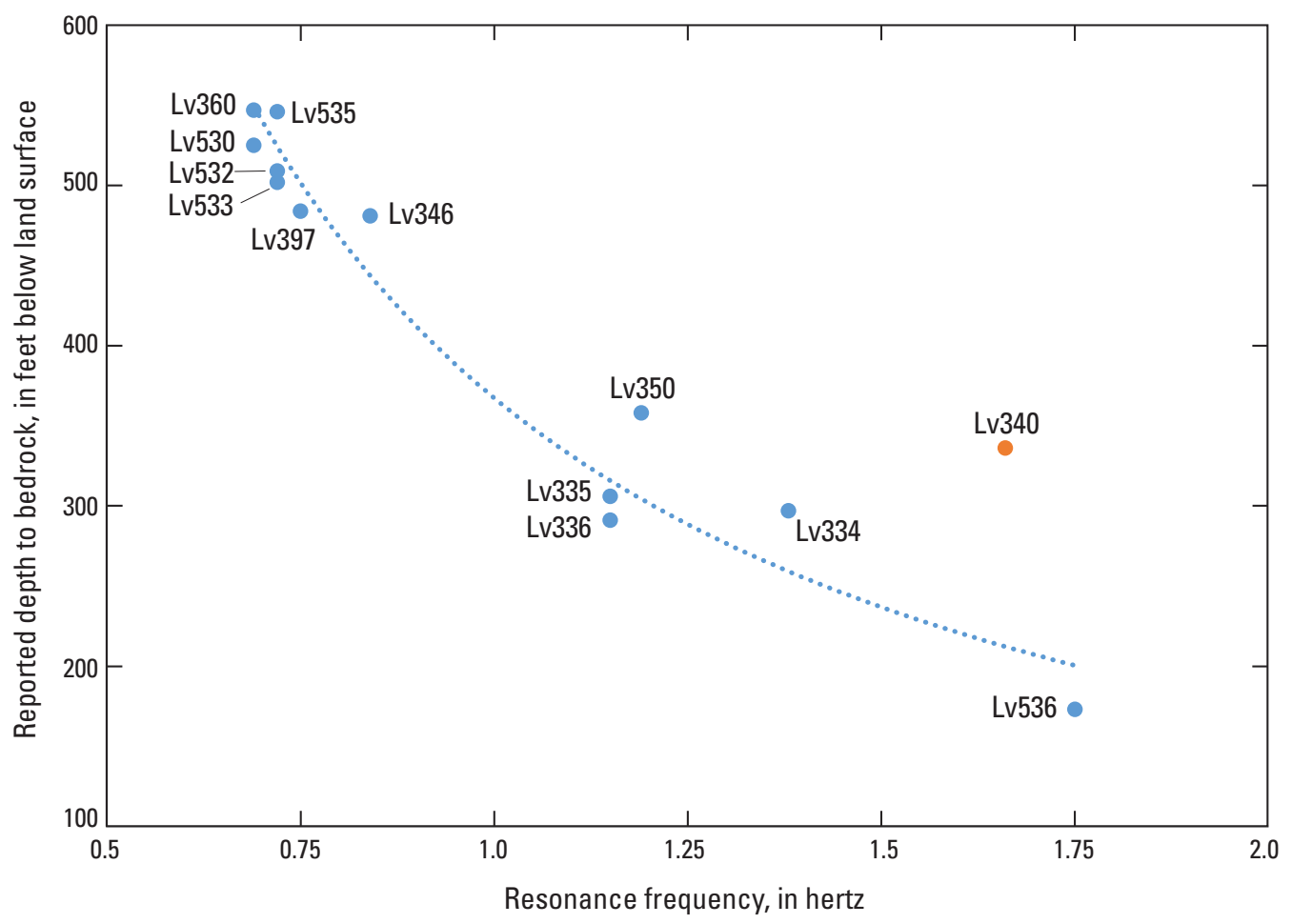

Figure 3. Regression of peak-resonance frequencies from passive-seismic measurements with reported depths to bedrock at wells in the Genesee River Valley in western New York. Blue dots indicate reported depth to bedrock from each well used in the regression; the orange dot identifies data for well Lv340, which was not used in the development of the regression equation.

spectral-ratio curves, fundamental resonance-frequency peaks, and reported and estimated depths to bedrock are available from Heisig and others (2021).

\section{Well Logs}

Geologic logs from drilling samples from 18 wells were analyzed to characterize the lithostratigraphy of the valley fill and upper bedrock along and between the 13 TDEM and passive seismic transects in the Genesee River Valley (table 1). Gamma logs from seven of the wells were used in the lithostratigraphic analysis. Resistivity and electromagnetic logs from four wells provided some limited information on the electrical conductivity of the valley fill and shallow bedrock. The well logs had been collected as part of previous saltextraction and related activities and mine-collapse investigations in the river valley. The geologic logs are available from the Empire State Organized Geologic Information System (New York State Department of Environmental Conservation, 2019), and the geophysical logs are available from the USGS well-log database (U.S. Geological Survey, 2019).

\section{Groundwater Samples for Salinity}

Groundwater-sample analyses were compiled to provide information on the historic distribution of salinity in the valley fill and bedrock to aid in the interpretation of the TDEM soundings (table 1). Salinity and chloride data have been collected in the Genesee valley-fill aquifer system as part of salt-extraction activities since the start of solution mining in the early 1890s. Multiple monitoring wells were installed after the mine collapse and were used for monthly chloride sampling from 1994 through 1996. Monthly samples for chlorides were collected from 2004 through 2014 from a groundwatersampling network that was established in the Genesee River Valley as part of a brine-mitigation activity (Alpha Geoscience, 2000; Akzo Nobel Salt Inc., written commun., 2014). The network included wells that were actively pumped for brine mitigation and monitoring wells in and near the collapse area. Of the nine wells monitored for chloride concentration, some monitored only one zone, and others monitored up to eight zones. The lower confined aquifer was monitored by six wells, and other wells monitored the underlying bedrock at various depths. Semiannual samples for chlorides were collected from 1997 to 2014 from monitoring wells north and south of the collapse area and from domestic water-supply wells north of the collapse area near Fowlerville, New York (Akzo Nobel Salt Inc., written commun., 2014). The compiled chloride and salinity data, including data sources, are available from Kappel and Williams (2021). 


\section{Geologic Setting}

The Genesee River Valley was formed by tectonic uplift and subsequent fluvial downcutting of Paleozoic sedimentary rocks, glacial erosion of the bedrock, and deposition of a thick complex sequence of glacial sediments, which were then modified by postglacial streams. The bedrock, glacial, and postglacial geology of the Genesee River Valley described by Yager and others (2001) is summarized in the following sections.

\section{Bedrock Geology}

The salt-bearing and overlying rocks in the Genesee River Valley are sedimentary units of Silurian and Devonian age that include the following formations, in ascending order: the Vernon Shale, Syracuse Formation, Camillus Shale, Bertie Limestone, Onondaga Limestone, and the Marcellus and younger Devonian shales (figs. 4 and 5). The regional dip of the bedrock strata is less than 1 degree to the south. A regional unconformity separates the Late Silurian Bertie Limestone from the Middle Devonian Onondaga Limestone. The Onondaga Limestone subcrop forms the shallowest part of the buried bedrock surface along the central part of the Genesee River Valley in the study area. The Devonian shales underlie the eastern and western edges and walls of the valley and the uplands.

\section{Glacial and Postglacial Geology}

Glacial erosion deepened the preglacial Genesee River Valley by as much as $600 \mathrm{ft}(180 \mathrm{~m})$ and widened it, creating a concave, north-south bedrock profile. The eroded bedrock surface of the resistant Onondaga Limestone slopes southward from Fowlerville near the north end of the study area, where it subcrops at an altitude of approximately $400 \mathrm{ft}(120 \mathrm{~m})$, to the south end of study area, where it subcrops near Sonyea at an altitude of approximately $50 \mathrm{ft}(15 \mathrm{~m}$; fig. 4). The unconsolidated sediments that partly fill the Genesee River Valley were deposited during glacial advances and retreats and, to a lesser extent, during postglacial time (fig. 4). Subglacial meltwater deposits of sand and gravel overlie the bedrock valley floor. The basal deposits are overlain by a thick sequence of englacial and lacustrine deposits including variably silty sand, gravel, till, and fine sand, silt, and clay. A relatively thin layer of supraglacial meltwater deposits of sand and gravel overlie the englacial and lacustrine deposits. Above the supraglacial sand and gravel, thick deposits of lacustrine and deltaic sand, silt, and clay are present. An apparent till layer consisting of reworked and compacted lacustrine sediments with some stones marks a possible ice readvance (figs. 4 and 5). The Fowlerville Moraine fills the valley in the northernmost part of the study area (figs. 1 and 5). Overlying the glacial deposits are fluvial and alluvial sediments, including sand and gravel deposited as fans and in stream channels, and overbank fine sand, silt, and clay.

\section{Hydrologic Setting}

The valley-fill aquifer system in the Genesee River Valley is underlain and bounded by bedrock and consists of three aquifers separated by two confining units (fig. 6; Yager and others, 2001). The hydrologic setting of the aquifer system in the Genesee River Valley was described by Yager and others (2001) and is summarized in the following sections.

\section{Aquifer and Confining Units}

The valley-fill aquifer system consists of an unconfined aquifer, upper confining unit, middle confined aquifer, lower confining unit, and lower confined aquifer (fig. 6). The degree of hydraulic connection among these three aquifers in areas along the edges of the valley, where the confining units may be thin or absent, is not well characterized. The upper aquifer consists of saturated fluvial and alluvial sediments below the water table and above the upper confining unit. The contact between the upper aquifer and the upper confining unit is nearly flat. The upper confining unit separates the upper aquifer from the middle aquifer and consists of lacustrine fine-grained sediments and till. The confining unit is bounded locally by coarser deposits near the valley walls (for example, through deltaic deposits near Mount Morris) that provide some hydraulic connection between the upper and middle aquifers (fig. 1). The confined middle aquifer consists of sand and gravel and has an undulating upper surface. The lower confining unit that separates the middle and lower aquifers consists of lacustrine and till deposits. Glaciofluvial deposits, if locally present, would provide hydraulic connection between the middle and lower aquifers. The lower confined aquifer overlies the bedrock valley floor and consists of glaciofluvial sand and gravel.

The fractured and solutioned upper part of the underlying Onondaga Limestone in the bedrock valley bottom is considered part of the lower confined aquifer, effectively increasing its transmissivity and lateral continuity. Fractures in the shales that form the bedrock valley walls provide limited connections between the lower confined aquifer and bedrock aquifers in the bordering uplands. Water-bearing zones in the bedrock underlying the Genesee valley-fill aquifer system are aligned along nearly horizontal bedding-plane fractures near stratigraphic contacts. The principal bedrock water-bearing zone underlying the valley is a fracture zone near the contact between the Onondaga and Bertie Limestones (fig. 5).

\section{Groundwater Flow}

Groundwater within the valley originates as precipitation onto the valley floor and the surrounding uplands and discharges to the Genesee River and Canaseraga Creek and their tributaries (fig. 1) or as underflow to downgradient areas. Groundwater flow is generally northward through the aquifer system, and discharge is to the major streams. The upper 


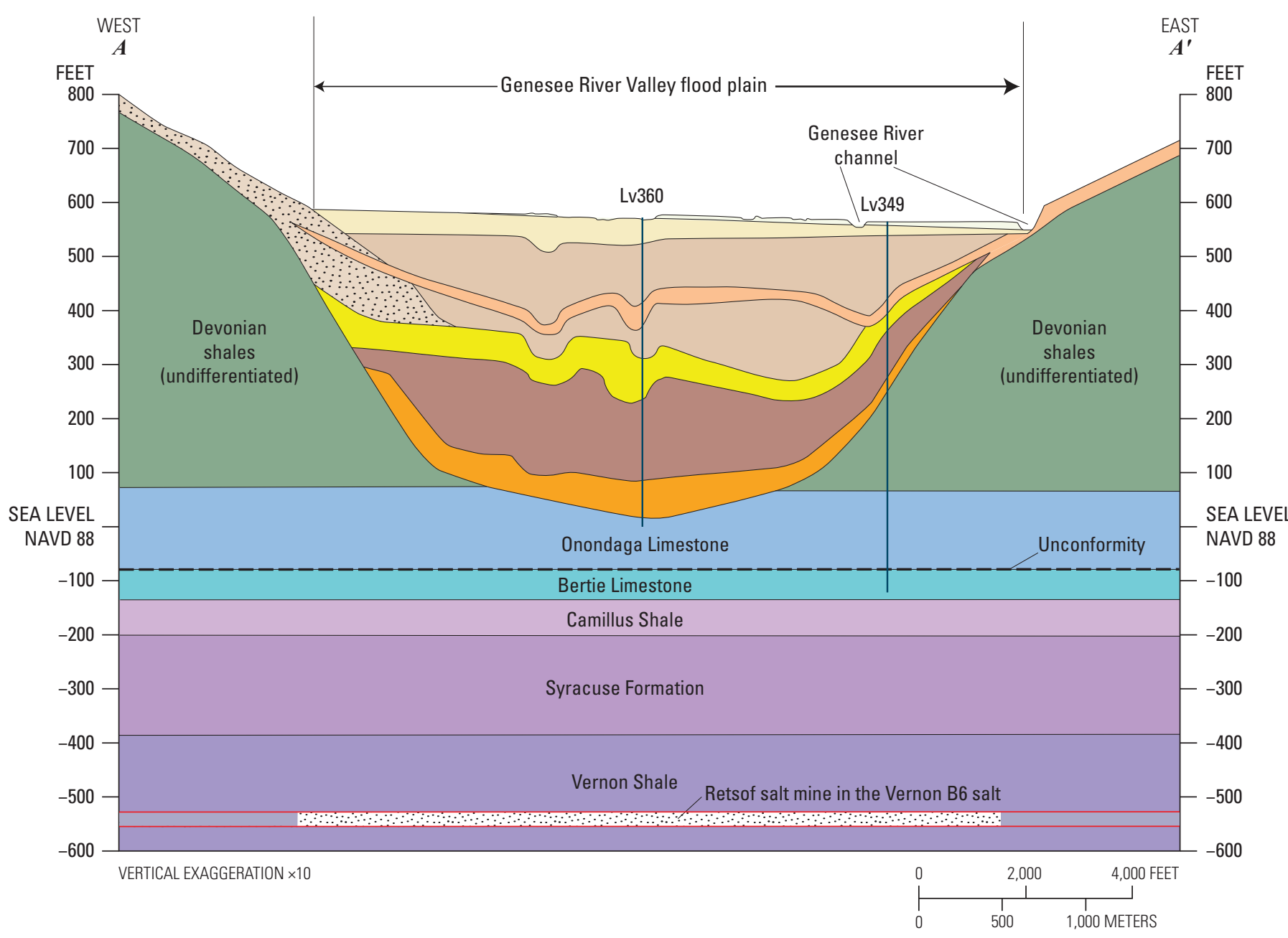

\section{EXPLANATION}

\section{Unconsolidated deposit}

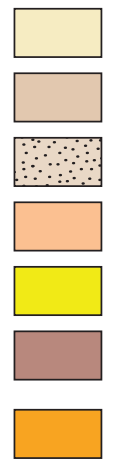

Alluvial-fan and flood-plain deposit-Silt, sand, and gravel

Lacustrine sand, silt, and clay

Deltaic deposit—Pebbly sand

Till—Dense silt and clay embedded with pebbles

Supraglacial debris-Silty sand and gravel

Englacial meltout material and subaqueous deposit-Mix of clay, silt, sand, and gravel

Subglacial meltwater deposit—Sand and gravel

\section{Lv349 Well and U.S. Geological Survey (USGS)}

well number-Number and Lv prefix

(Livingston County) assigned by the USGS

\section{Extent of the Vernon B6 salt}

Figure 4. Generalized geologic section across the Genesee River Valley in western New York; modified from Yager and others (2001). Location of section shown on figure 1. NAVD 88, North American Vertical Datum of 1988. 


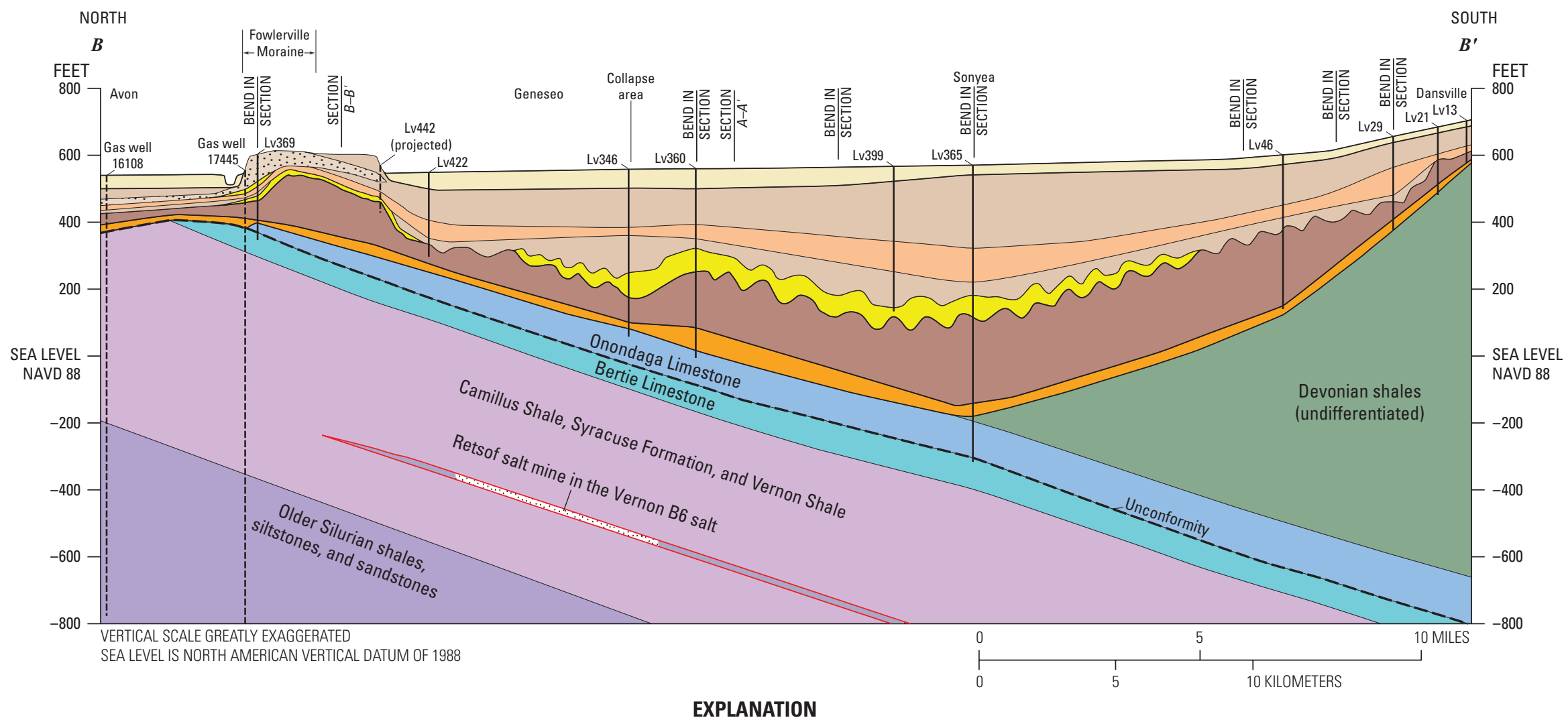

Unconsolidated deposit

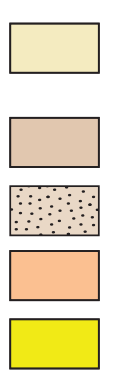

Alluvial-fan and flood-plain deposit-Silt, sand, and gravel

Lacustrine sand, silt, and clay

Deltaic deposit-Pebbly sand

Till—Silt and clay embedded with pebbles

Supraglacial debris-Silty sand and gravel

Englacial meltout material and subaqueous-fan deposit—Mix of clay, silt, and sand and gravel

Subglacial meltwater deposit-Sand and gravel

Lv349

Well and U.S. Geological Survey (USGS) well number-

Dashed where projected. Numbers with Lv prefix

(Livingston County) were assigned by the USGS. Numbers

for gas wells were assigned by the New York State Department

of Environmental Conservation

Extent of the Vernon B6 salt

Figure 5. Generalized geologic section along the axis of the Genesee River Valley in western New York; modified from Yager and others (2001). Location of section shown on figure 1. NAVD 88, North American Vertical Datum of 1988. 


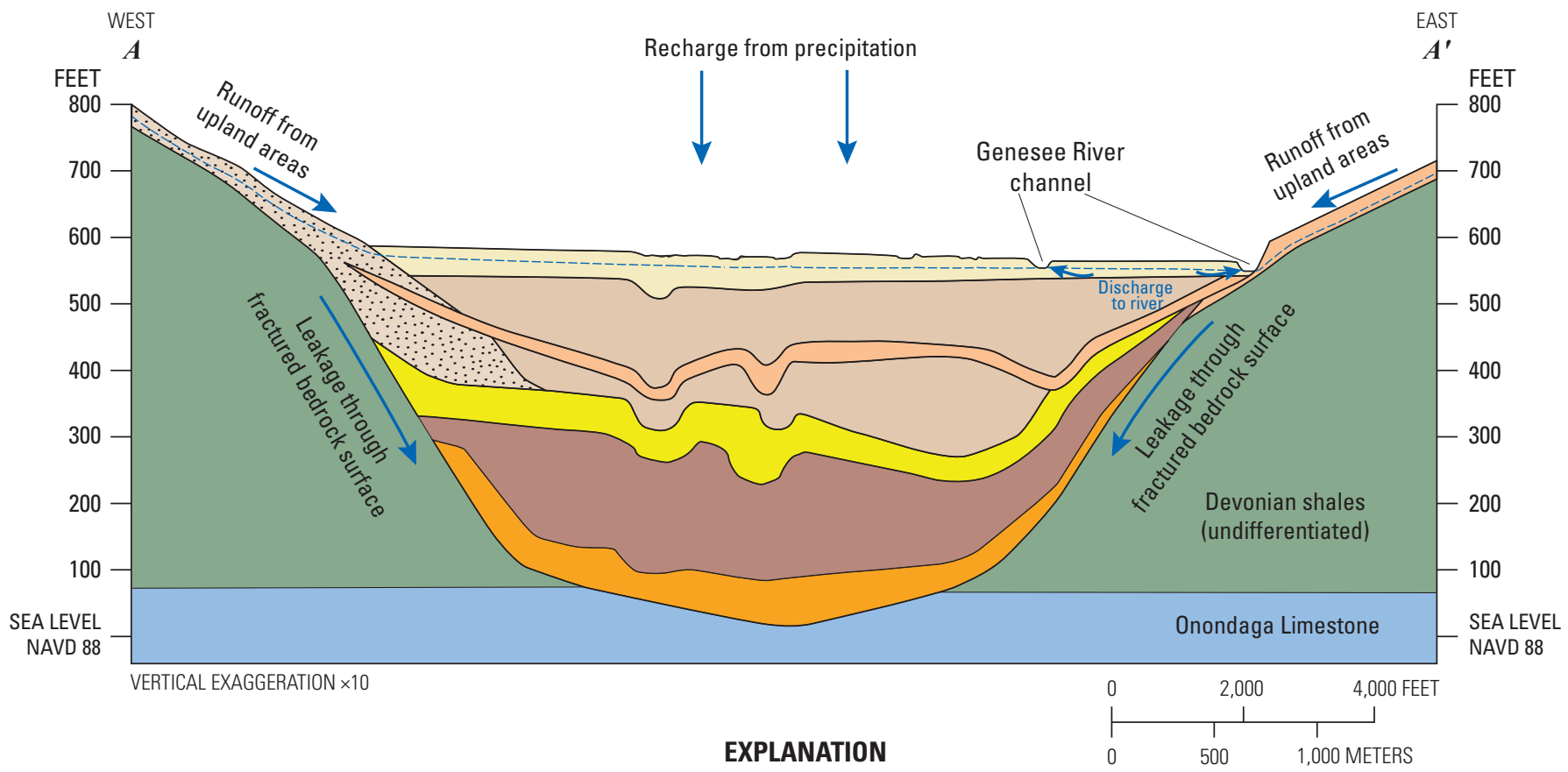

Unconsolidated deposit

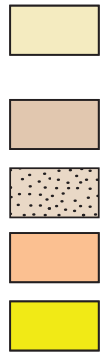

Alluvial-fan and flood-plain deposit-Silt, sand, and gravel

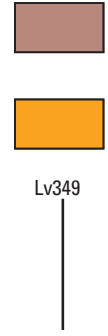

Englacial meltout material and subaqueous-fan deposit-Mix of clay, silt, and sand and gravel

Lacustrine sand, silt, and clay

Subglacial meltwater deposit—Sand and gravel

Deltaic deposit—Pebbly sand

Till—Silt and clay embedded with pebbles

Supraglacial debris—Silty sand and gravel

Well and U.S. Geological Survey (USGS) well number-

Dashed where projected. Numbers with Lv prefix

(Livingston County) were assigned by the USGS. Numbers

for gas wells were assigned by the New York State Department of Environmental Conservation

Water table in upper aquifer

Direction of water flow

Figure 6. Generalized hydrogeologic section across the Genesee River Valley in western New York; modified from Yager and others (2001). Location of section shown on figure 1. NAVD 88, North American Vertical Datum of 1988.

aquifer is recharged by infiltration of precipitation on the valley floor and runoff from the uplands. The middle and lower confined aquifers are recharged through the Valley Heads Moraine southeast of Dansville and locally along the sides of the valley wall. Groundwater discharges from the aquifers as underflow to the north of the study area. Hydraulic heads in the confined aquifers beneath the valley floor under natural conditions are believed to be higher than in the aquifers, but any upward leakage is severely limited by the overlying confining units.

\section{Distribution of Fresh and Saline Groundwater}

\section{Valley-Fill Aquifer System}

Groundwater in the upper aquifer in the Genesee valleyfill aquifer system is fresh. Groundwater in the middle aquifer is relatively fresh with specific-conductance values of 400 to 1,400 microsiemens per centimeter at 25 degrees Celsius $(\mu \mathrm{S} / \mathrm{cm})$ and chloride concentrations of 25 to 140 milligrams per liter (mg/L; Yager and others, 2001; Kappel and Williams, 2021). The salinity of groundwater in the lower aquifer is higher and more variable than that in the middle aquifer. Groundwater from the lower confined aquifer in the collapse area, whose salinity was assumed to represent the salinity before the collapse, had specific-conductance values of 1,000 to $2,500 \mu \mathrm{S} / \mathrm{cm}$ and chloride concentrations of about $500 \mathrm{mg} / \mathrm{L}$ (Williams, 1996; Kappel and Williams, 2021). 
Groundwater samples from wells in the lower aquifer in the Fowlerville area had specific-conductance values that ranged from 1,450 to $12,400 \mu \mathrm{S} / \mathrm{cm}$ and chloride concentrations that ranged from 300 to $4,300 \mathrm{mg} / \mathrm{L}$ (Kappel and Williams, 2021). The ratio of chloride to bromide concentrations in the high salinity samples might be the result of water mixing with the saline waters in the Bertie Limestone unit.
In the lower aquifer, the most saline groundwater, which had a specific conductance of $39,300 \mu \mathrm{S} / \mathrm{cm}$ and a chloride concentration of $14,300 \mathrm{mg} / \mathrm{L}$, was sampled in 1995 from borehole Lv397 (figs. 7 and 8; Kappel and Williams, 2021). Geophysical and drilling logs at this well site indicated the presence of fresh water in the middle aquifer and saline water in the lower aquifer in 1979 (fig. 8). The 1979 logs and the

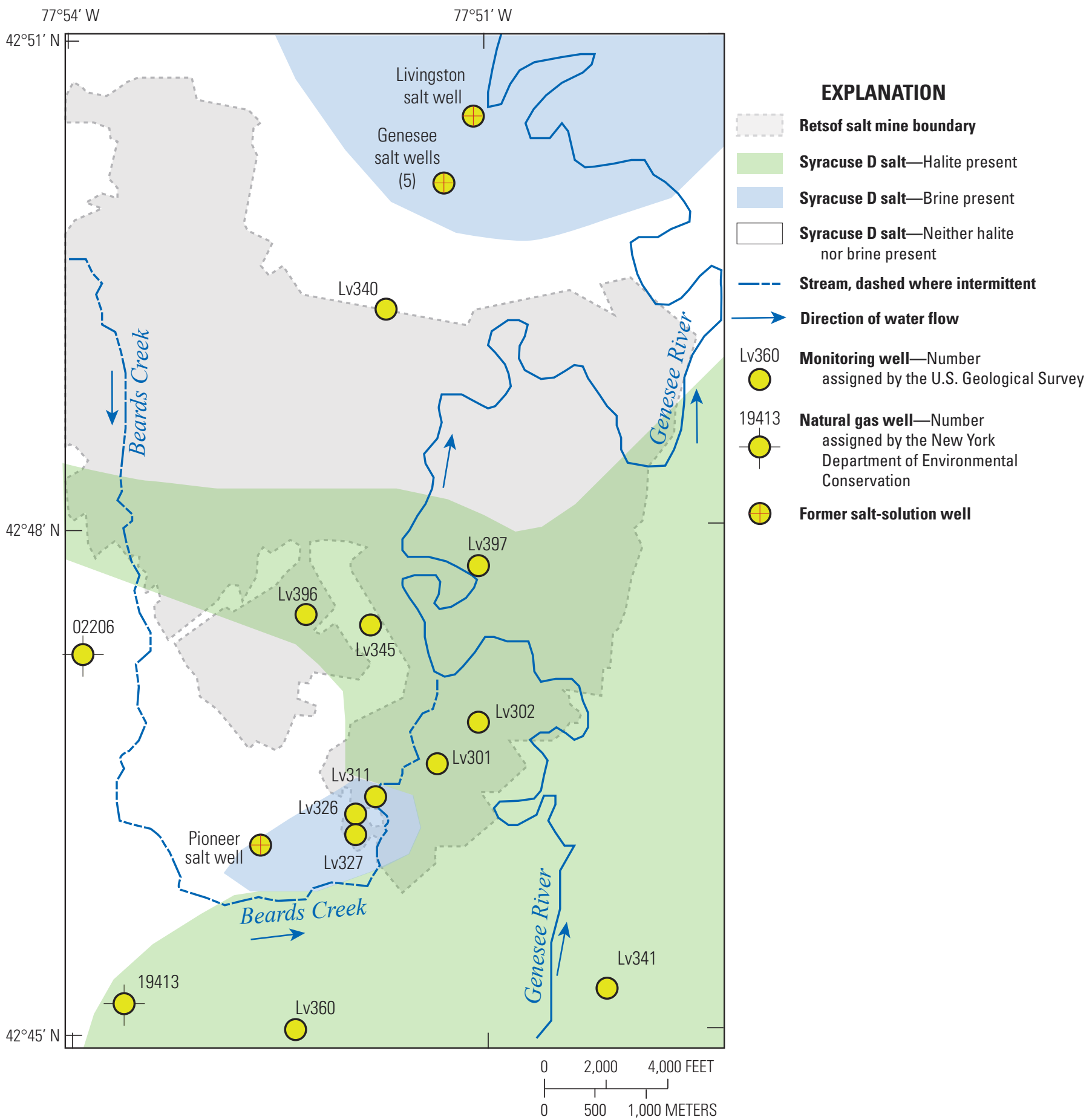

Figure 7. Distribution of the Syracuse D salt and brine pools in the Genesee River Valley in western New York; modified from Gowan and Trader (2000, p. 68, fig. 14). 


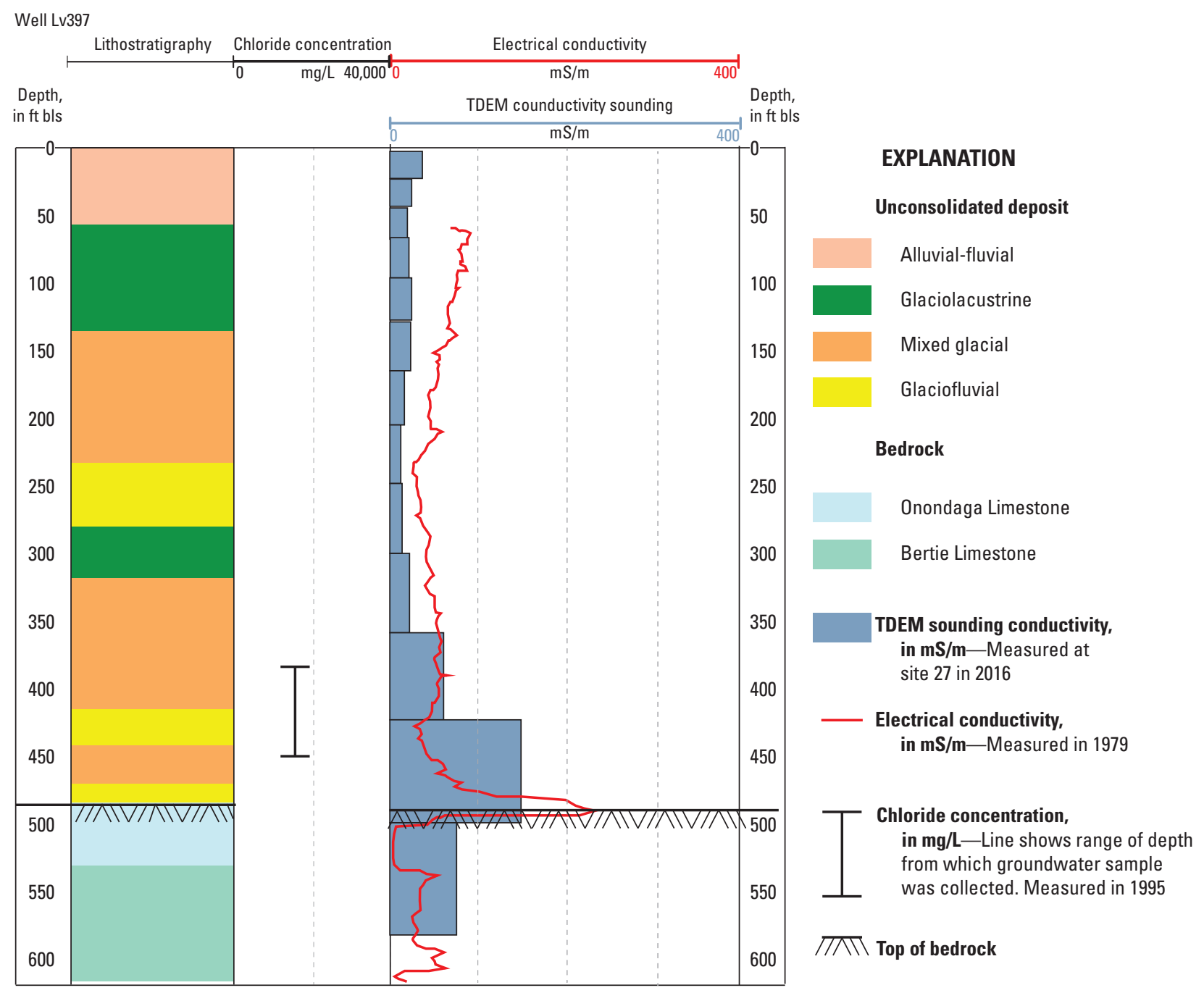

Figure 8. Log of lithostratigraphy, chloride concentration in groundwater sampled from retrofitted borehole Lv397 in 1995, log of electrical conductivity measured in 1979, and the results of the 2016 time-domain electromagnetic (TDEM) sounding at nearby site 27 in the Genesee River Valley in western New York. Locations of borehole and sounding site shown on plate 1. ft, foot; bls, below land surface; $\mathrm{mS} / \mathrm{m}$, millisiemens per meter; $\mathrm{mg} / \mathrm{L}$, milligram per liter.

ratio of chloride to bromide concentrations in a water sample from the well in 1995 indicate that the salinity of groundwater in the lower aquifer in this area might have been affected by salt-mining- or salt-solution-related activities before the mine collapse (Yager and others, 2001).

\section{Onondaga and Bertie Limestones}

Groundwater in the fracture zones of the Onondaga and Bertie Limestones is saline. The specific conductance measured in groundwater samples collected in 1994 from several wells near the collapse area in the Onondaga and Bertie Limestone zones increased with depth and ranged from 10,000 to $50,000 \mu \mathrm{S} / \mathrm{cm}$ (Williams, 1996). Yager and others (2001) noted that the ratios of the chloride to bromide concentrations of water in the Onondaga and Bertie Limestones were close to those reported for nearby oil-field brines pumped from carbonates in western New York.

\section{Salt-Solution Wells}

Salt from the Salina evaporite beds was also extracted by solution through multiple wells along the western valley wall of the Genesee River Valley during the late 1800s (pl. 1). The salt-solution sites included the Phoenix, Genesee, Livingston, and York wells. Leakage during these salt-extraction operations or from the abandoned and unplugged solutioning wells could have contaminated groundwater in bedrock-fracture zones and one or more aquifers in some areas. 


\section{Syracuse D Salt and Brine Pools}

The initial water flow that resulted from the mine collapse and entered the 2 Yard South and 11 Yard West panel rooms (rooms mined in the Vernon B6 salt unit) was a combination of brine and natural gas followed by less saline water from bedrock-fracture zones and the lower confined aquifer (Gowan and Trader, 2000, fig. 7). Geologic and geophysical data were assessed from waters in the well network along the floor of the Genesee Valley as well as from former solution-mining operations that had taken place in the late 1800s (fig. 7). The data from the solution-mining wells were used to identify several locations along the western side of the Genesee River Valley, where natural brine and pressurized natural-gas pools were in the Syracuse D salt unit. Just west of the southern end of the mine near the hamlet of Cuylerville (fig. 1), the former Pioneer Salt Company (later named Phoenix Dairy Company) solution-mining well penetrated a pressurized brine pool where the Syracuse D salt unit was presumed to have been. The pressurized brine and natural gas were used to lift brine developed in the lower Vernon B salt to the land surface. In a similar fashion, near the hamlet of Piffard, which is north of the Retsof mine, two solution-mining operations (Genesee Salt Co. and Livingston Salt Co.) were active, and a similar Syracuse D pressurized brine pool was present instead of salt. Gowan and Trader (2000, p. 68) summarized the distribution of the Syracuse D salt and brine pools in the Genesee River Valley (fig. 7). The Syracuse D salt, as halite, is generally present south and east of the collapse area but absent north and west of the collapse area-however, there are some locations where the salt bed is present only as a brine. The brine pools presumably were developed by fresh groundwater that dissolved the Syracuse D salt. During glaciation, highly pressured subglacial waters may have been forced downward through fractures and dissolved the salt bed in these areas.

\section{Devonian Shales}

In several locations along the flanks of the Genesee River Valley, natural gas and pockets of saline water have been reported in some shallow domestic wells that tap the Devonian shales. A 160-ft deep domestic well drilled in 2003 along the eastern valley wall reportedly yielded saline water from the fractured top of bedrock (S.W. Gowan, Alpha Geoscience, oral commun., 2017). Saline water with elevated chloride concentrations has been reported for other domestic wells completed in Devonian shales of western and central New York. This saline water is believed to be a remnant of salty water that had not been flushed out of the shale by active groundwater circulation.

\section{Hydrologic Effects of Mine Collapse}

\section{Mine Collapse, Rubble Chimneys, and Flooding}

The roofs in two yielding-pillar mining panels or rooms in the southern part of the Retsof mine collapsed during the spring of 1994. Yielding-pillar technology was being used in the mine to mitigate the increased occurrence of mine floor heaves and mine roof collapses, in one case resulting in the deaths of two miners. The mine collapse, rubble-chimney development, and flooding were described by Yager (2013) and are summarized below.

On March 12, 1994, the roof over the mine panel 2 Yard South collapsed, and saline water began to flow into the mine. Over the next several weeks, as Akzo attempted to save the mine by pumping water out and drilling around the collapse area to inject cement grout into the collapsed room and thus prevent further inflow of water, unstable shale and evaporite layers overlying the panel sagged and collapsed to form a roughly circular zone of rock rubble (collapse chimney) that propagated upward. The propagating collapse chimney eventually reached the Onondaga Limestone, which was strong enough to temporarily halt further collapse and upward progression of the rock-rubble chimney. At this time, the flow of water into the previously dry (unflooded) mine was about 5,500 gallons per minute (gal/min; 21,000 liters per minute $[\mathrm{L} / \mathrm{min}])$. Much of the inflow probably was from the fracture zone near the Onondaga-Bertie contact (labeled "unconformity" on fig. 9).

On April 6, 1994, the Onondaga Limestone at the floor of the valley collapsed into the void created below this resistant bedrock strata by the previous collapse in the mine and the void's propagation upwards through the intervening shale bedrock. The overlying valley-fill sediments quickly slumped downward into the resulting cavity creating a subsidence zone in the unconsolidated materials and forming a sinkhole at the land surface. Water from the lower confined aquifer drained downwards through the rock-rubble chimney into the mine (fig. 9). In mid-April, a second collapse in an adjacent mining panel (11 Yard West) resulted in the development of a second rock-rubble chimney, unconsolidated subsidence zone, and eventually a sinkhole at land surface. Inflow to the mine through the two rubble chimneys was about $18,000 \mathrm{gal} / \mathrm{min}(68,000 \mathrm{~L} / \mathrm{min})$, and all attempts to save the mine were abandoned.

Water filled the southern end of the mine and then spread steadily northward, dissolving the bases of the salt pillars that supported the mine roof. As the pillars gave way, the southern part of the mine began to collapse, causing the land surface above it to subside (fig. 10). The greatest subsidence was beneath the two sinkholes, which altered the channel of Beards Creek and forced the closure of the bridge over Beards Creek. More widespread subsidence north and south of the collapse area altered patterns of sediment scour and deposition in the Genesee River and widened its flood plain. 


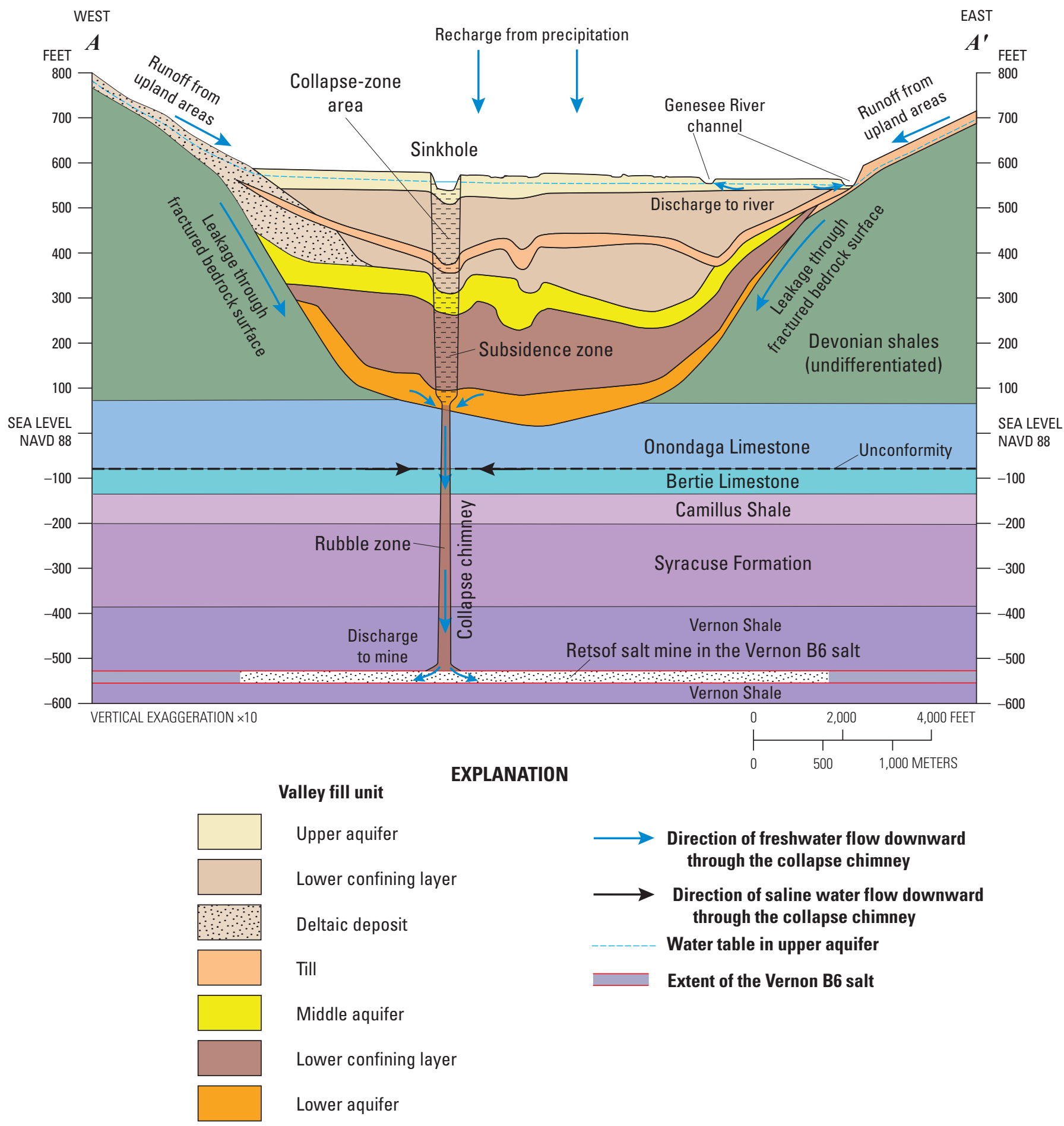

Figure 9. Generalized hydrogeologic section across the Genesee River Valley in western New York, following the development of a rubble chimney, surface sinkhole, and flooding into the mine; modified from Yager and others (2001). Location of section shown in figure 1. NAVD 88, North American Vertical Datum of 1988. 


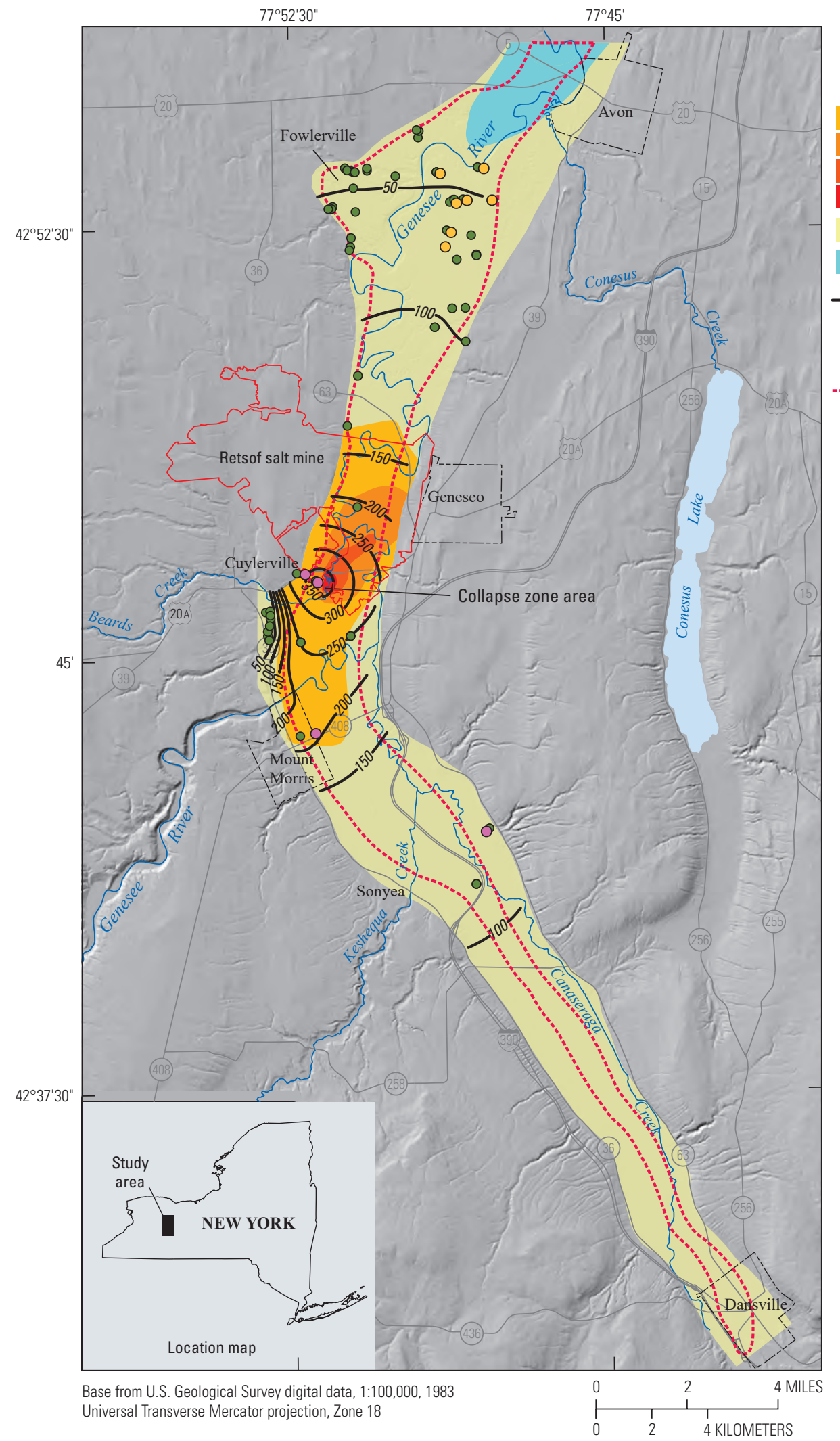

\section{EXPLANATION}

Land subsidence, in feet

$>0$ to 1

$>1$ to 5

$>5$ to 35

$>35$

Unconsolidated deposit with valley fill

Saline water area in Bertie Limestone

-100 - Water-level decline in lower confined aquifer-Contour interval 50 feet; datum is North American Vertical Datum of 1988

Lower confined aquifer boundaryShown dashed because approximately located

- Well that produced gas

O Well that produced saline water-Specific conductance more than 2,500 microsiemens per centimeter at 25 degrees Celsius

- Well where water-level decline was observed

Figure 10. Land subsidence, water-level drawdowns, and wells in which water levels declined, became saline, or produced gas after the mine collapse, in the Genesee River Valley in western New York; modified from Yager (2013). 


\section{Groundwater-Level Decline and Salinity Increase}

Discharge from the valley-fill aquifer system through the rubble chimneys and into the mine substantially affected groundwater levels, gradients, and salinity. The first wells to be affected by the water-level declines had been completed in the lower confined aquifer, whereas wells completed in the middle-confined aquifer were affected later. By June 1994, water levels had declined by $100 \mathrm{ft}(30 \mathrm{~m})$ in wells as far as $3 \mathrm{mi}(5 \mathrm{~km})$ away from the collapse area and by as much as $35 \mathrm{ft}(11 \mathrm{~m})$ in wells $8 \mathrm{mi}$ to the north (fig.10; Yager, 2013).

Chloride concentrations measured in water samples from five wells in the lower confined aquifer near Fowlerville, $8 \mathrm{mi}$ to the north of the collapse area (fig. 10), increased during spring 1995. This increase in salinity probably resulted from the southward movement of saline groundwater from an area underlain by the subcrop of the Bertie Limestone that contained brackish water (figs. 9 and 11). Water-level decline in the lower confined aquifer had caused the hydraulic gradient in the Fowlerville area to reverse southward and thus allow saline water to flow into areas that previously had fresh water. Declining water levels also resulted in the production of natural gas in several wells.

\section{Groundwater-Level Recovery}

After the total flooding of the Retsof mine in early 1996, the lower confined aquifer slowly began to be recharged by groundwater flowing from the Dansville Moraine in the south, the flanks of the Genesee River Valley, and Fowlerville Moraine in the north. Water levels in the lower confined aquifer took nearly a decade to recover to precollapse conditions (Yager and others, 2001).

\section{Upward Flow of Saline Water Through Rubble Chimneys}

After totally flooding, the mine was filled with saturated brine, and the Onondaga-Bertie and other saline-water-bearing fracture zones remained hydraulically connected to the lower confined aquifer through the two rubble chimneys (fig. 12). The open mine cavity slowly closed as unmined salt pillars deformed under the weight of the overlying bedrock and valley-fill sediments, in a process known as "mine squeeze," that will continue at a diminishing rate for more than 100 years (John T. Boyd Co., 1995). An estimated 80 percent of the 16 billion gallons of saturated brine that fills the mine is expected to eventually be displaced upward through the rubble chimneys (L.L. Van Sambeek, RE/SPEC, Inc., written commun., 2007). With the recovery to precollapse hydraulic gradients, saline water from the Onondaga-Bertie and deeper bedrock-fracture zones could also have the potential to flow upwards through the rubble chimneys.
In 2002, groundwater-quality monitoring in the lower confined aquifer near the collapse area provided the first evidence of increased salinity levels resulting from the hydraulic connection provided by the rubble chimneys. Samples of the halite brine in the rubble chimneys had chloride concentrations of about $180,000 \mathrm{mg} / \mathrm{L}$ in fall 2005. Groundwater sampled from the lower confined aquifer just north of the collapse area had a chloride concentration of about $20,000 \mathrm{mg} / \mathrm{L}$ at this time. The saline water from the lower confined aquifer appeared to be solely a mixture of bedrock fracture-zone water and aquifer water, indicating that brine from the mine had not reached the lower confined aquifer (Yager and others, 2009; Yager, 2013).

\section{Remedial Pumping to Mitigate Saline-Water Migration}

A brine-mitigation project to pump water from the collapse area began in September 2006 to limit the effects of the upward flow of saline water into the lower confined aquifer (Gowan and others, 2005; Alpha Geoscience, 2007; Gowan, 2013). Saline water and brine were pumped from four wells in the collapse area initially at a rate of $70 \mathrm{gal} / \mathrm{min}(270 \mathrm{~L} / \mathrm{min})$ and thereafter at a sustained rate of $25 \mathrm{gal} / \mathrm{min}(95 \mathrm{~L} / \mathrm{min})$. The pumped water was processed through an onsite desalination plant. The remedial pumping continued through 2013, when pumping ceased, and the plant was shut down under an agreement between representatives of Akzo and New York State.

Monitoring of chloride concentrations in groundwater before, during, and after pumping indicated that the mitigation project had significantly reduced salinity levels in the lower confined aquifer near the collapse area (Kappel and Williams, 2021). Chloride concentrations sampled from well Lv309, which were believed to be representative of the brine in the rubble chimneys, were about $200,000 \mathrm{mg} / \mathrm{L}$ and remained relatively stable during the monitoring period (fig. 13A).

Chloride concentrations sampled from well Lv322, which was completed in the lower confined aquifer just northeast of the collapse area, were about near 20,000 mg/L before pumping started, rapidly decreased after pumping started, and were about 2,000 mg/L when pumping stopped (fig. 13B). Chloride concentrations rapidly increased after pumping stopped and were about $12,000 \mathrm{mg} / \mathrm{L}$ when monitoring ended in 2014 . The initial chloride concentration and responses indicate that the prepumping hydraulic gradient in the lower confined aquifer was predominantly to the north and that there was a good hydraulic connection between the aquifer and a continuous source of saline water from the rubble chimneys.

Chloride concentrations sampled from well Lv531, which was completed in the lower confined aquifer just east of the collapse area, were about 2,500 $\mathrm{mg} / \mathrm{L}$ before the start of pumping, continuously decreased after pumping started, and were about $1,000 \mathrm{mg} / \mathrm{L}$ when pumping stopped (fig. 13C). Chloride concentrations remained virtually the same after pumping stopped and until the monitoring ended. The initial chloride concentration and response to pumping suggest a 


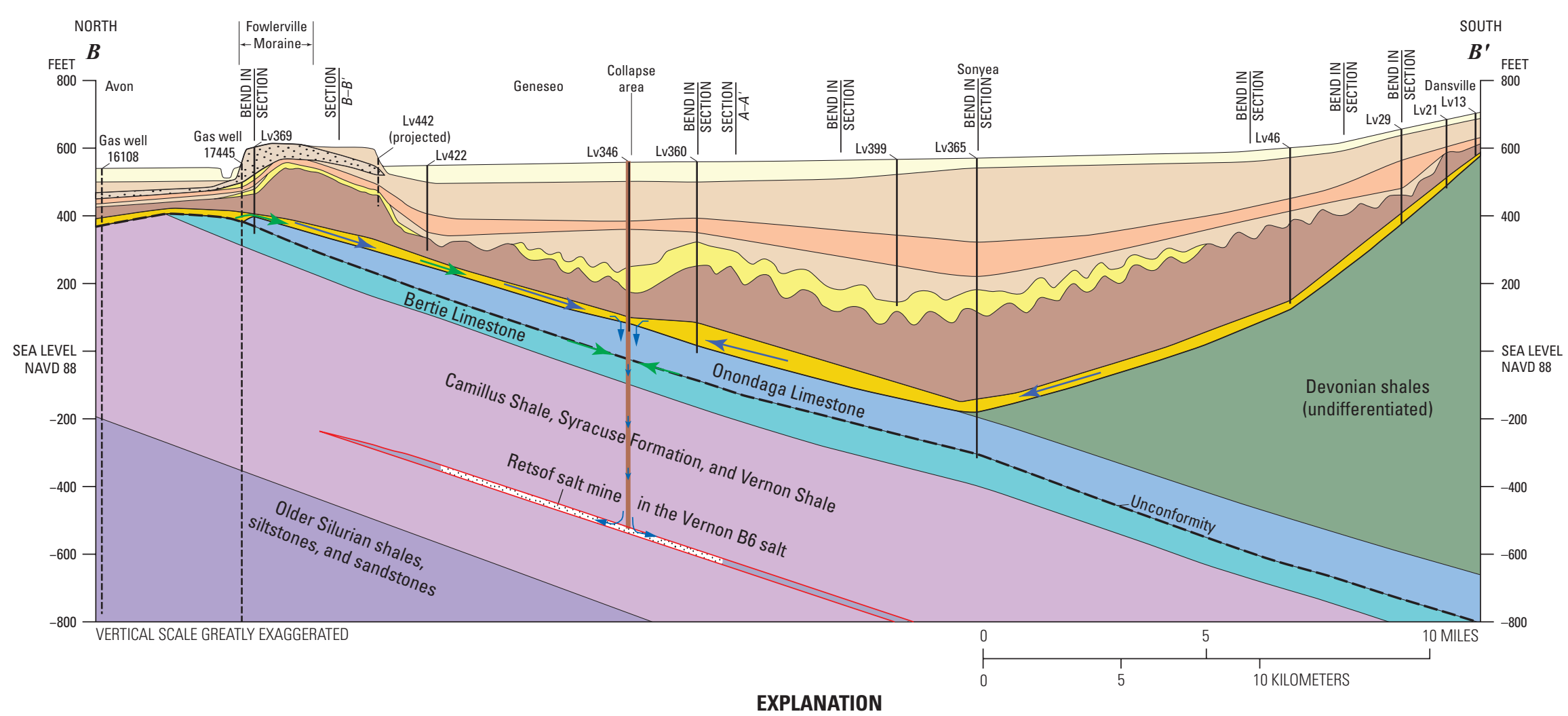

\section{Unconsolidated deposit}

Alluvial-fan and flood-plain deposit-Silt, sand, and gravel

Lacustrine sand, silt, and clay

Deltaic deposit—Pebbly sand

Till—Silt and clay embedded with pebbles

Supraglacial debris-Silty sand and gravel

Englacial meltout material and subaqueous-fan deposit-Mix of clay, silt, and sand and gravel

Subglacial meltwater deposit-Sand and gravel

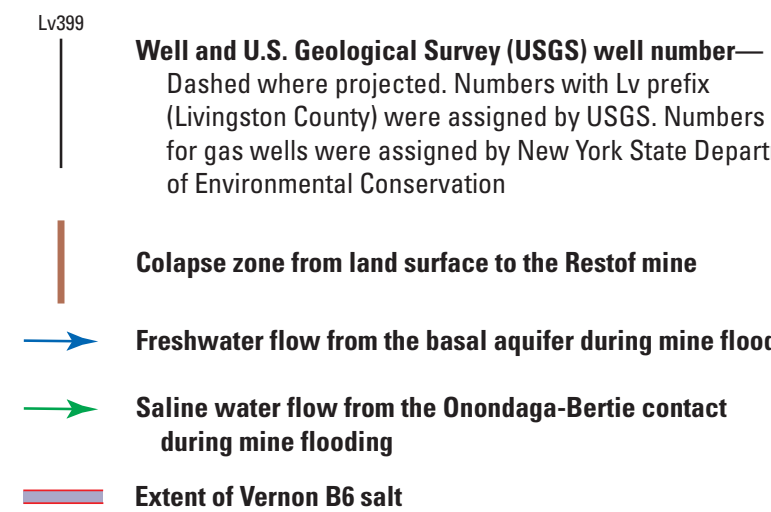

Figure 11. Generalized hydrogeologic section along the axis of the Genesee River Valley in western New York during mine flooding, with southward movement of saline groundwater from the Bertie Limestone during mine flooding; hydrologic section modified from Yager and others (2001). Location of section shown on figure 1. NAVD 88, North American Vertical Datum of 1988. 


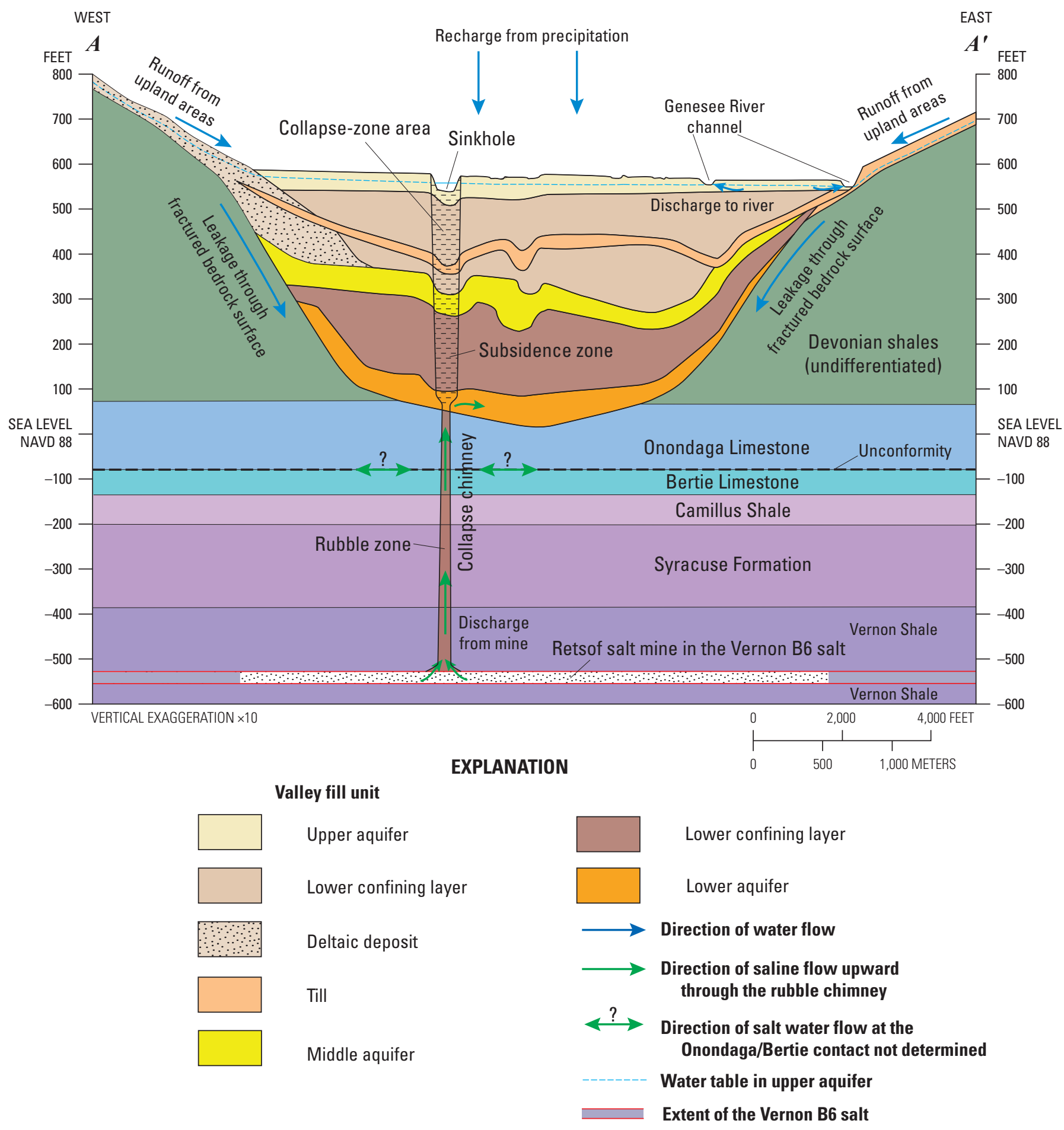

Figure 12. Generalized hydrogeologic section across the Genesee River Valley in western New York, showing upward flow of saline water through the rubble chimneys and into the lower confined aquifer after complete mine flooding and aquifer recovery; modified from Yager and others (2001). Location of section shown on figure 1. NAVD 88, North American Vertical Datum of 1988. 

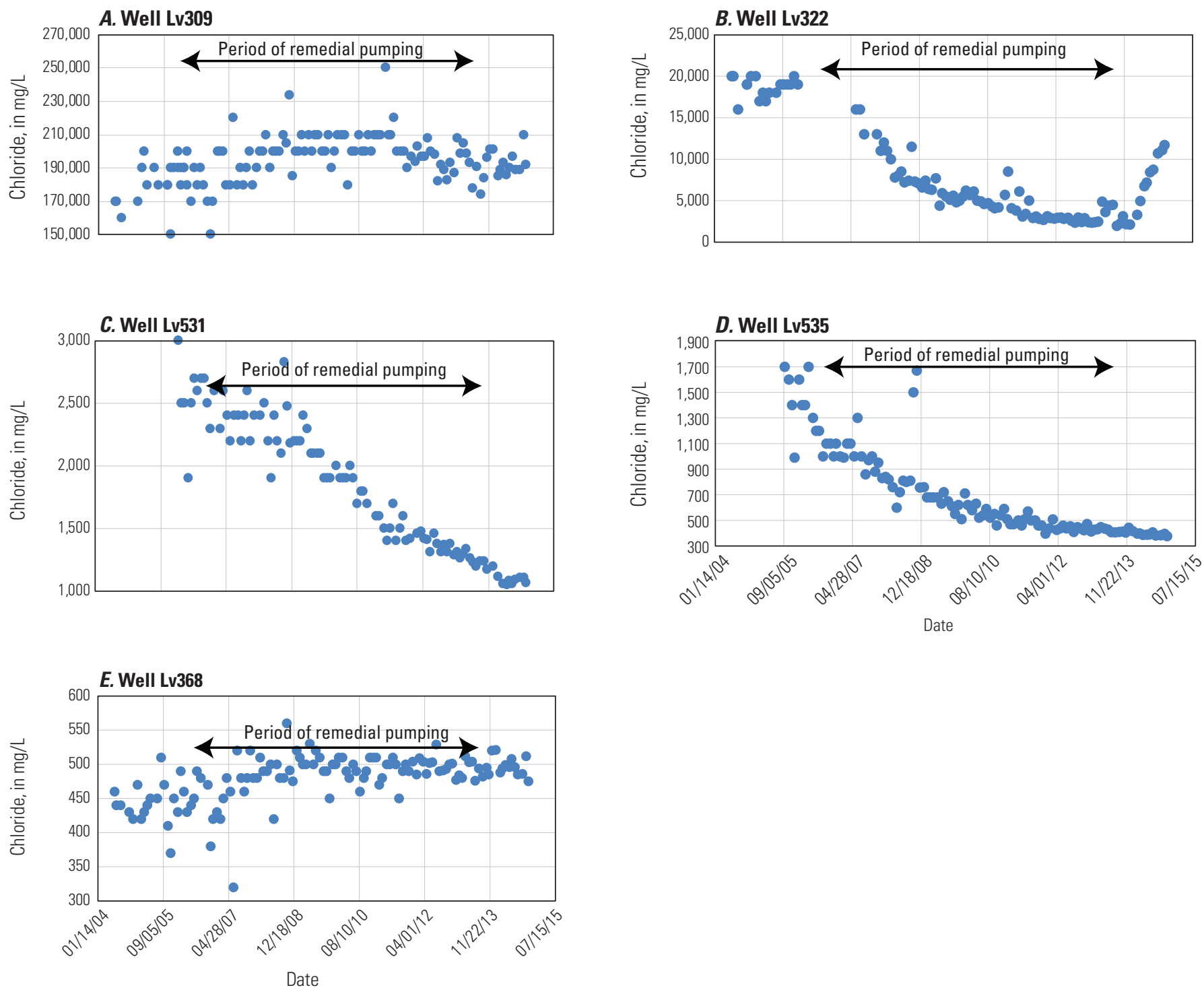

Figure 13. Chloride concentrations in groundwater sampled from wells $A$, Lv309 (Syracuse Shale aquifer within the rubble chimney area), $B$, Lv322 (lower confined aquifer northeast of the rubble chimney area), $C$, Lv531 (lower confined aquifer east of the rubble chimney area), $D$, Lv535 (lower confined aquifer south of the rubble chimney area), and $E$, Lv368 (lower confined aquifer west of the rubble chimney area) in the Genesee River Valley in western New York from 2006 to 2014. Location of wells shown on plate 1. mg/L, milligram per liter.

slight eastward component to the hydraulic gradient in the lower confined aquifer, which in this area might be hydraulically connected to the rubble chimneys but not to the extent of its connection in the north.

Chloride concentrations sampled from well Lv535, which was completed in the lower confined aquifer south of the collapse area, were more than $1,500 \mathrm{mg} / \mathrm{L}$ before the start of pumping, rapidly decreased when pumping started, and were near $400 \mathrm{mg} / \mathrm{L}$ when pumping stopped (fig. 13D). Chloride concentrations remained virtually the same after pumping stopped until the end of monitoring. The low chloride concentrations after pumping stopped reflected replacement of the original water by fresher water in the lower confined aquifer from the south.

Chloride concentrations sampled from well Lv368, which was completed in the lower confined aquifer just west of the collapse area, reached about $500 \mathrm{mg} / \mathrm{L}$ before the start of pumping. These concentrations, which remained the same throughout the pumping and monitoring period, are consistent with either a northeastern hydraulic gradient or the lack of a hydraulic connection between the lower confined aquifer in this area and the rubble chimneys (fig. 13E). 


\section{Delineation of Saline Groundwater in the Valley-Fill Aquifer System}

The 2016-17 cross-valley transects of the valley-fill aquifer system and underlying bedrock, which were used to measure electrical conductivity determined from the TDEM soundings and top-of-bedrock altitudes estimated from the passive-seismic measurements, are presented on plate 1 . These transects connect wells where logs of water depth were made and chloride samples were taken that could provide information about the distribution of saline groundwater in the valleyfill aquifer system, potential sources of such groundwater, and migration pathways. In general, the cool colors displayed on the transects indicate conductivity values less than about 50 millisiemens per meter at 25 degrees Celsius $(\mathrm{mS} / \mathrm{m})$, which are associated with fresh water, and the warm colors indicate conductivity values greater than about $50 \mathrm{mS} / \mathrm{m}$, which are associated with saline water.

\section{Transects South of the Collapse Area}

The transects south of the collapse area included Perry Road, Jones Bridge Road, and Cuyler Road (pl. 1, transects 1, 2 , and 3). The transect along Perry Road was the southernmost transect. The valley-fill aquifer system along the Perry Road transect displayed low electrical conductivity in the central part of the valley underlain by the Onondaga Limestone. Chloride concentrations in groundwater sampled in 1995 from the lower confined aquifer at well Lv360, which may be representative of 2016-17 salinity levels in the aquifer in the central part of the valley, were less than $300 \mathrm{mg} / \mathrm{L}$ (Kappel and Williams, 2021). On the eastern and western edges of the valley, shallow Devonian bedrock known to contain saline water displayed elevated electrical conductivity. Groundwater sampled in 1996 from the lower confined aquifer above Devonian shale at well Lv350, which may be representative of 2016-17 salinity levels in this valley-edge setting, had a chloride concentration of more than 2,100 mg/L. Groundwater sampled in 1995 from the middle confined aquifer at companion well Lv351 had a chloride concentration of $125 \mathrm{mg} / \mathrm{L}$.

The next transect north of Perry Road (transect 2) was the Jones Bridge Road transect. The valley-fill aquifer system along Jones Bridge Road displayed low electrical conductivity in the main valley underlain by the Onondaga Limestone. Groundwater sampled at the end of brine-mitigation pumping in 2014 from the lower confined aquifer just south of Perry Road at well Lv535 had chloride concentrations less than $400 \mathrm{mg} / \mathrm{L}$; this value might be representative of 2016-17 salinity levels in the central part of the valley aquifer (fig. 13D). Along the Jones Bridge Road transect in the east central part of the main valley, the Onondaga-Bertie bedrock just above the TDEM depth of investigation displayed elevated electrical conductivity, which may be related to density-driven flow of dense saline water from the nearby collapse area (Yager and others, 2009); however, there is no indication of elevated electrical conductivity in the bedrock in a similar position along the Perry Road transect to the south. As along the Perry Road transect, shallow Devonian bedrock on the eastern and western valley edges of the Jones Bridge Road transect displayed elevated electrical conductivity.

The Cuyler Road transect was just south of the collapse area. The lower confined aquifer and the Onondaga Limestone along the Cuyler Road transect displayed elevated electrical conductivity in the central part of the valley. Groundwater sampled at the end of brine-mitigation pumping in 2014 from the Onondaga at well Lv530 had chloride concentrations of about $10,000 \mathrm{mg} / \mathrm{L}$, which is probably higher than 2016-17 salinity levels in the lower confined aquifer. To the east and west of the central part of the main valley, the lower confined aquifer displayed low electrical conductivity. Groundwater sampled at the end of brine-mitigation pumping in 2014 from the lower confined aquifer at well Lv346 had chloride concentrations of less than $600 \mathrm{mg} / \mathrm{L}$, which may be representative of 2016-17 salinity levels in the aquifer in the area.

\section{Transects North of Collapse Area}

The transects north of the collapse area included Route 20A, Beets field, Farm Road, Big Tree Lane, and Hemp Pond Lane (pl. 1, transects 4, 5, 6, 7, and 8). In the central part of the valley from the Route $20 \mathrm{~A}$ transect to the Hemp Pond Lane transect, a distance of $2.6 \mathrm{mi}$, the lower confined aquifer displayed an approximately 3,000-ft-wide zone of high electrical conductivity. Sampled before the start of brine-mitigation pumping in 2006 from the lower confined aquifer at well Lv322, groundwater salinity levels with chloride concentrations of about $20,000 \mathrm{mg} / \mathrm{L}$ might be representative of 2016-17 salinity levels in the central-valley part of the aquifer along the Route 20A transect (figs. 13B and 14). Saline water flowing upward through the rock-rubble chimneys and mixing with northward groundwater flow in the lower confined aquifer is likely a major source of chlorides for this high-conductivity zone; however, the reported presence of saline water in the lower confined aquifer during drilling and delineated by electrical-conductivity logging in borehole Lv397 when drilled in 1979 (fig. 7) indicates that the chimney area is not the only source of high-chloride groundwater. Groundwater sampled in 1995 from the lower confined aquifer at retrofitted well Lv397 had chloride concentrations of about 14,000 mg/L (Kappel and Williams, 2021). The straightforward interpretation of the rubble chimneys being the source for saline water is further complicated by the very high conductivity measured in the lower confined aquifer in the main valley along the Hemp Pond Lane transect. This higher conductivity might be related to transient changes in salinity sourced from the collapse area, saline water migrating south from other sources farther to the north due to the reversal of hydraulic gradients to the south during the mining flooding period, and historical density-driven migration of saline water along the upper fractured and solutioned bedrock from brine sources to the north. 


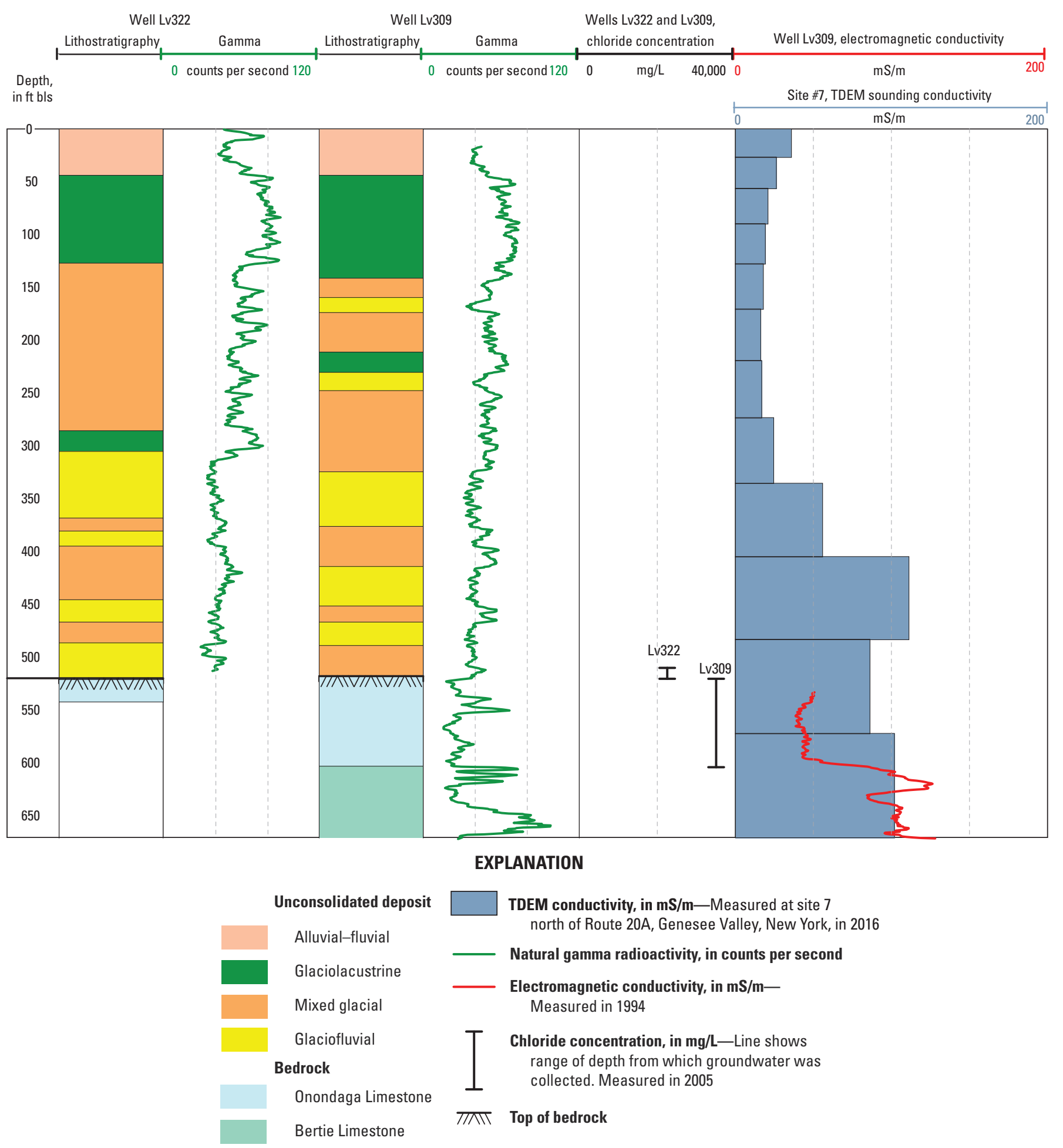

Figure 14. Lithostratigraphy and natural gamma and electromagnetic-conductivity logs from 1994 for boreholes Lv322 and Lv309, chloride concentrations in sampled groundwater in 2005, and time-domain electromagnetic (TDEM) sounding log from 2016 for nearby site 7, north of Route 20A, in the Genesee River Valley in western New York. Locations of borehole and sounding site shown on plate 1. $\mathrm{ft}$, foot; bls, below land surface; $\mathrm{mS} / \mathrm{m}$, millisiemens per meter; $\mathrm{mg} / \mathrm{L}$, milligram per liter. 
Like the transects south of the collapse area, the shallow Devonian shale underlying the valley edges along these transects generally displayed elevated electrical conductivity. An electromagnetic-conductivity log collected in 1994 from borehole Lv345 located just to the west of the central part of the valley delineated elevated conductivity in the lower confined aquifer (fig. 15). The source of saline water may be the nearby Devonian shale; the presence of the saline water in 1994 could not be related to flow from the collapse area.

\section{Transects East of Piffard}

The transects east of Piffard included Chandler Road, Flats Road, and Route 63 North, (pl. 1, transects 9, 10, and 11). In the central and west-central part of the valley along
Chandler Road, the upper Onondaga Limestone displayed high electrical conductivity. When drilled in 1994 in the western part of the valley, well Lv340 produced $200 \mathrm{gal} / \mathrm{min}$

$(760 \mathrm{~L} / \mathrm{min})$ of water with an estimated chloride concentration of about $18,000 \mathrm{mg} / \mathrm{L}$ from just below the top of the Onondaga Limestone at $339 \mathrm{ft}(103 \mathrm{~m})$ below land surface (bls). In the central part of the valley along the Flats Road and Route 63 North transects, the lower confined aquifer and uppermost bedrock displayed very high electrical conductivity. When well Lv421 was drilled in 1957 on the western valley edge just north of Piffard, it penetrated a confined sand-and-gravel aquifer at a depth of 75 to $110 \mathrm{ft}$ ( 23 to $34 \mathrm{~m}$ ) bls that produced salty water (Kappel and Williams, 2021). Abandoned leaking wells from historical salt-solution mining in the 1890 s along the western edge of valley at and just north of Piffard

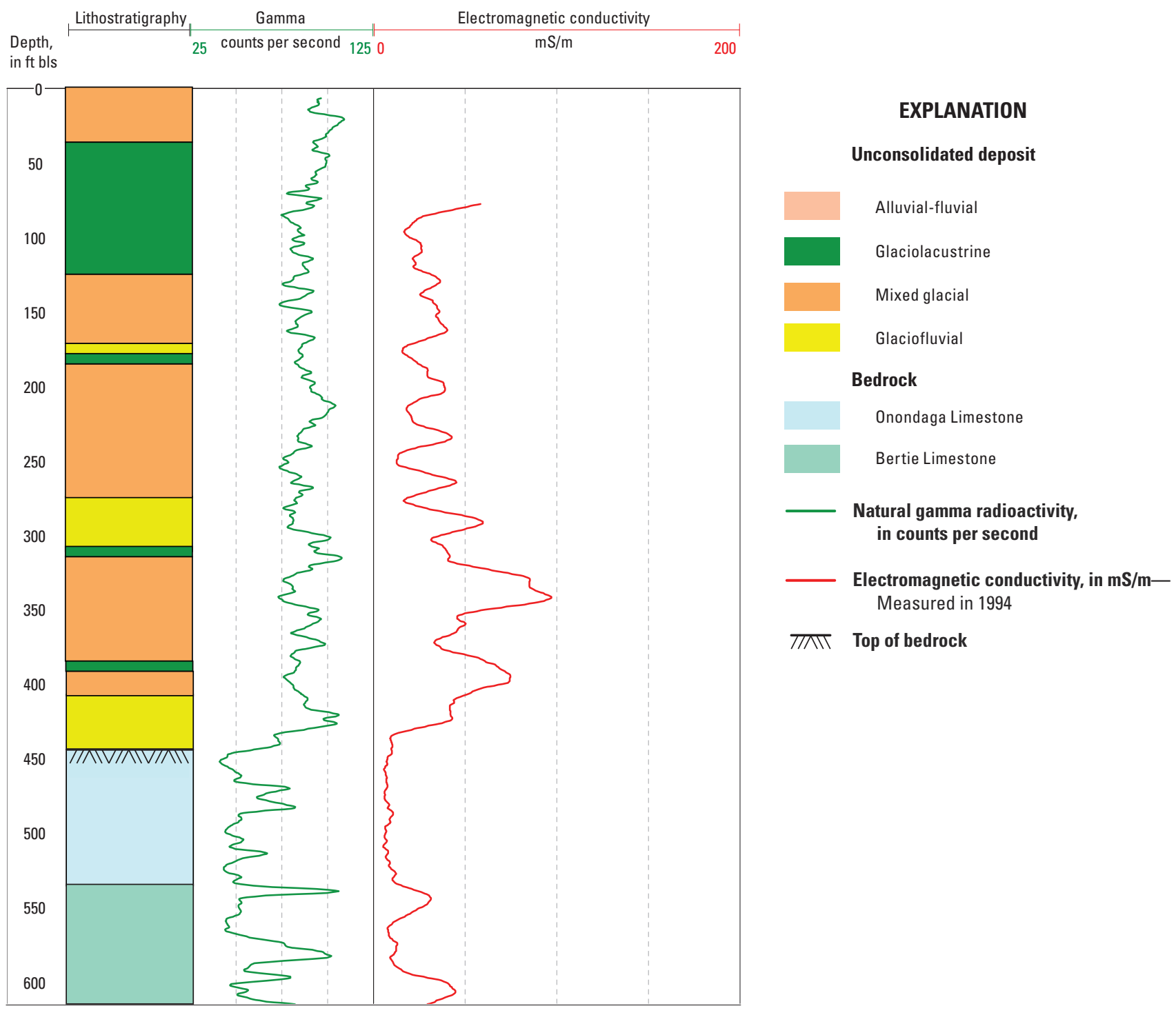

Figure 15. Lithostratigraphy and gamma and electromagnetic-conductivity logs from 1994 from borehole Lv345 in the Genesee River Valley in western New York. Location of borehole site shown on plate 1. $\mathrm{ft}$, foot; bls, below land surface; $\mathrm{mS} / \mathrm{m}$, millisiemen per meter; $\mathrm{mg} / \mathrm{L}$, milligram per liter. 
are the probable source of high-salinity groundwater in the area. A possible additional source of saline water in the area is the northern Syracuse D salt brine pool (fig. 7), although the history, mechanism, and pathway of migration from the brine pool to the uppermost bedrock in the valley is not clear.

\section{Fowlerville Moraine Transects}

The Fowlerville transects included Nations Lane and Oxbow Lane (pl. 1, transects 12 and 13). The lower valley fill and upper bedrock in the central part of the valley along the Nations Lane and Oxbow Lane transects displayed low electrical conductivity. Well Lv335 drilled in 1999 in the central part of the valley along the Nations Lane transect penetrated a thick basal sequence of sand and gravel overlying fractured and solutioned Onondaga Limestone that reportedly produced $600 \mathrm{gal} / \mathrm{min}(2,300 \mathrm{~L} / \mathrm{min})$ of fresh water. Groundwater samples collected from the well from 1999 to 2013, which probably are representative of 2016-17 salinity levels in the basal valley fill and uppermost bedrock in the area, had chloride concentrations that ranged from 380 to $780 \mathrm{mg} / \mathrm{L}$ (Kappel and Williams, 2021). The shallow elevated electrical conductivity in the central and eastern part of the Nations Lane transect may be caused by the presence of surficial clayey till.

The upper bedrock in the western part of the valley along the Nations Lane transect and the eastern and western parts of the valley along the Oxbow Lane transect displayed slightly elevated electrical conductivity. Well Lv334 drilled in 1999 near the eastern edge of the valley along the Oxbow Lane transect reportedly produced salty water and an oil show (a petroleum smell or sheen) from fractures at depths of 305 to $315 \mathrm{ft}$ (93.0 to $96.0 \mathrm{~m}$ ) bls in the Onondaga Limestone (Alpha Geoscience, 2000). The salinity concentration in a groundwater sample collected from the well in 2000, which may be representative of 2016-17 salinity concentrations in the upper bedrock in the area, was 46,000 mg/L. Well Lv336 drilled in 1999 near the eastern edge of the valley between the Oxbow Lane and Nations transects was reported to have penetrated a productive water zone in basal glaciofluvial deposits at a depth of 277 to $288 \mathrm{ft}$ ( 84.4 to $87.8 \mathrm{~m}$ ) bls (Alpha Geoscience, 2000). Salinity levels in groundwater samples collected from the well in 2012 and 2013, which probably are representative of 2016-17 salinity levels in the lower confined aquifer in the area, had chloride concentrations that ranged from 3,400 to $4,300 \mathrm{mg} / \mathrm{L}$.

\section{Summary}

The U.S. Geological Survey, in cooperation with the New York State Department of Environmental Conservation, used noninvasive surface geophysics in the investigation of the distribution of saline groundwater in the valley-fill aquifer system of the Genesee Valley near the former Retsof salt mine in western New York. In 1994, the roof of two mining panels in the Retsof salt mine, which was the largest of its kind in the western hemisphere at the time, collapsed catastrophically, resulting in groundwater inflow from the valley-fill and bedrock aquifer system into the mine through two bedrockrubble chimneys. Since the early 2000 s, except for a period of remedial pumping from 2006 to 2013, high-salinity water has migrated upward through the bedrock-rubble chimneys and into the confined lower part of the valley-fill aquifer system. The extent of saline-water migration within the aquifer system had not been evaluated since the end of remedial pumping, when all the monitoring wells were grouted shut and abandoned. Installation of a monitoring-well network would be expensive and difficult given the thickness and heterogeneous character of the valley fill. An investigation of the current extent of saline water in the aquifer system was warranted because the basal part of the aquifer is shallower to the north and it is used for water supply.

In fall 2016 and fall 2017, the U.S. Geological Survey collected time-domain electromagnetic (TDEM) soundings at 105 sites along 13 cross-valley transects north and south of the mine-collapse area. The TDEM soundings were colocated with passive seismic measurements to determine the bedrocksurface elevation through use of a regression equation developed from measurements at well sites with reported bedrock depths in the study area.

An analysis of the TDEM soundings combined with the depth-to-bedrock estimates, borehole logs, and chloridemonitoring data indicates the presence of a zone of high electrical conductivity associated with saline water in the confined, lower part of the valley-fill aquifer system. The delineated saline-water zone extends more than 2.5 miles (4.0 kilometers) northward from the mine collapse area. The chloride concentration in groundwater within this high-conductivity zone might be as high as 20,000 milligrams per liter. Saline water flowing upward through the bedrock-rubble chimneys and mixing with northward groundwater flow in the lower confined aquifer is believed to be a major source of chlorides in this high-conductivity zone. The zone's northern extent is unclear because of the presence of higher salinity zones delineated by the TDEM soundings and possibly associated with historical brine wells or possibly sourced by natural brine pools east of Piffard in the lower confined aquifer and uppermost bedrock. 


\section{References Cited}

Alpha Geoscience, 2000, Summary and hydrogeologic interpretations of data from AKZO cluster wells and residential wells near Fowlerville, New York: Akzo Nobel Salt Inc., 23 p., 5 apps., 3 pls.

Alpha Geoscience, 2007, December 2006 quarterly report for the AKZO brine mitigation project: Akzo Nobel Salt Inc., 9 p.

Archie, G.E., 1942, The electrical resistivity log as an aid in determining some reservoir characteristics: Petroleum Transactions of the AIME, v. 146, p. 54-62.

Auken, E., Christiansen, A.V., Jacobsen, L., and Sørensen, K.I., 2008, A resolution study of buried valleys using laterally constrained inversion of TEM data: Journal of Applied Geophysics, v. 65 , no. 1, p. 10-20, accessed July 2018, at https://doi.org/10.1016/j.jappgeo.2008.03.003.

Auken, E., Christiansen, A.V., Kirkegaard, C., Fiandaca, G., Schamper, C., Behroozmand, A.A., Binley, A., Nielsen, E., Effersø, F., Christensen, N.B., Sørensen, K., Foged, N., and Vignoli, G., 2015, An overview of a highly versatile forward and stable inverse algorithm for airborne, groundbased and borehole electromagnetic and electric data: Exploration Geophysics, v. 46, no. 3, p. 223-235, accessed July 2018, at https://doi.org/10.1071/EG13097.

Brown, C.J., Voytek, E.B., Lane, J.W., Jr., and Stone, J.R., 2013, Mapping bedrock surface contours using the horizontal-to-vertical spectral ratio (HVSR) method near the middle quarter area, Woodbury, Connecticut: U.S. Geological Survey Open-File Report 2013-1028, 4 p. [Also available at https://doi.org/10.3133/ofr20131028.]

Chandler, V.W., and Lively, R.S., 2014, Evaluation of the horizontal-to-vertical spectral ratio (HVSR) passive seismic method for estimating the thickness of Quaternary deposits in Minnesota and adjacent parts of Wisconsin: Minnesota Geological Survey Open-File Report 14-01, 52 p., accessed July 2018, at https://hdl.handle.net/11299/162792.

Christiansen, A.V., and Auken, E., 2012, A global measure for depth of investigation: Geophysics, v. 77, no. 4, p. WB171WB177, accessed July 2018, at https://doi.org/10.1190/ geo2011-0393.1.

Christiansen, A.V., Auken, E., and Sørensen, K., 2006, The transient electromagnetic method, in Kirsch, R., ed., Groundwater geophysics: Berlin, Heidelberg, SpringerVerlag, p. 179-225. [Also available at https://doi.org/ 10.1007/3-540-29387-6_6.]

Gowan, S.W., 2013, Report of the results of the Akzo brine pumping test and recommendations for the future: Alpha Geoscience, 73 p., 16 apps., 5 pls.
Gowan, S.W., and Trader, S.M., 2000, Mine failure associated with a pressurized brine horizon; Restof salt mine, western New York: Environmental \& Engineering Geoscience, v. 6, no. 1, p. 57-70, accessed September 23, 2019. [Also available at https://doi.org/10.2113/gseegeosci.6.1.57.]

Gowan, S.W., Nadeau, J.M., and Smith, J.N., 2005, Movement and control of brine rising from the Retsof salt mine eleven years after the collapse, in Spring Conference, Syracuse, New York, April 17-20, 2005, Proceedings: Solution Mining Research Institute, $17 \mathrm{p}$.

Heisig, P.M., Williams, J.H., Johnson, C.D., White, E.A., and Kappel, W.M., 2021, Horizontal-to-vertical spectral ratio and depth-to-bedrock data for saline-groundwater investigation in the Genesee valley, New York, OctoberNovember 2016 and 2017: U.S. Geological Survey data release, https://doi.org/10.5066/P9LI7CCR.

John, T., Boyd Co., 1995, Impact analysis-Retsof mine, Akzo Nobel Salt, Inc.: Pittsburgh, Pa., John T. Boyd Co., 50 p.

Johnson, C.D., and Lane, J.W., 2016, Statistical comparison of methods for estimating sediment thickness from horizontalto-vertical spectral ratio (HVSR) seismic methods-An example from Tylerville, Connecticut, USA, in Symposium on the application of geophysics to engineering and environmental problems 2016: Denver, Environmental and Engineering Geophysical Society, p. 317-323, at https://doi.org/10.4133/SAGEEP.29-057.

Kappel, W.M, and Williams, J.H., 2021, Chloride concentrations from wells in the Genesee River Valley, Livingston County, New York: U.S. Geological Survey data release, https://doi.org/10.5066/P9J354SU.

Lane, J.W., Jr., White, E.A., Steele, G.V., and Cannia, J.C., 2008 , Estimation of bedrock depth using the horizontalto-vertical (H/V) ambient-noise seismic method, in Symposium on the application of geophysics to engineering and environmental problems 2018: Denver, Environmental and Engineering Geophysical Society, p. 490-502, accessed June 2018, at https://doi.org/10.4133/1.2963289.

McNeill, J.D., 1994, Principles and application of time domain electromagnetic techniques for resistivity sounding: Mississauga, Canada, Geonics Limited Technical Note $\mathrm{TN}-27,16 \mathrm{p}$.

McNeill, J.D., 1980, Electrical conductivity of soil and rocks: Mississauga, Canada, Geonics Limited Technical Note $\mathrm{TN}-5,22 \mathrm{p}$.

Muller, E.H., and Cadwell, D.H., 1986, Surficial geologic map of New York-Finger Lakes sheet: New York State Museum Map and Chart Series 40, 1 pl. 
Nakamura, Y., 1989, A method for dynamic characteristics estimations of subsurface using microtremors on the ground surface: RTRI Quarterly Report [Japan], v. 30, p. 25-33.

New York State Department of Environmental Conservation, 2019, Data on oil, gas and other wells in New York state: New York State Department of Environmental Conservation web page, accessed June 23, 2019, at https://www.d ec.ny.gov/energy/1524.html.

Payne, J.D., and Teeple, A.P., 2011, Time-domain electromagnetic soundings collected in Dawson County, Nebraska, 2007-09: U.S. Geological Survey Data Series 581, 46 p. [Also available at https://doi.org/10.3133/ds581.]

Stewart, M., and Gay, M.C., 1986, Evaluation of transient electromagnetic soundings for deep detection of conductive fluids: Ground Water, v. 24, no. 3, p. 351-356. [Also available at https://doi.org/10.1111/j.1745-6584.1986.tb01011.x.]

U.S. Geological Survey, 2019, USGS GeoLog locator: U.S. Geological Survey database, accessed June 19, 2019, at https://webapps.usgs.gov/GeoLogLocator/.

White, E.A., Johnson, C.D., Williams, J.H., and Kappel, W.M., 2021, Time-domain electromagnetic soundings to delineate saline groundwater in the Genesee valley-fill aquifer system, New York (2016-2017): U.S. Geological Survey data release, https://doi.org/10.5066/P9VQOCRZ.
Williams, J.H., 1996, Application of borehole geophysics at the Retsof salt mine collapse site, western New York, in Symposium on the Application of Geophysics to Engineering and Environmental Problems, Keystone, Colo., April 28-May 1, 1996, [proceedings]: Englewood, Colo., Environmental and Engineering Geophysical Society, p. 813-821. [Also available at https://doi.org/10.4133/ 1.2922345.]

Yager, R.M., 2013, Environmental consequences of the Retsof Salt Mine roof collapse: U.S. Geological Survey Open-File Report 2013-1174, 10 p., accessed September 2018, at https://doi.org/10.3133/ofr20131174.

Yager, R.M., Miller, T.S., and Kappel, W.M., 2001, Simulated effects of 1994 salt-mine collapse on groundwater flow and land subsidence in a glacial aquifer system, Livingston County, New York: U.S. Geological Survey Professional Paper 1611, 85 p. [Also available at https://doi.org/ 10.3133/pp1611.]

Yager, R.M., Misut, P.E., Langevin, C.D., and Parkhurst, D.L., 2009, Brine migration from a flooded salt mine in the Genesee Valley, Livingston County, New YorkGeochemical modeling and simulation of variabledensity flow: U.S. Geological Survey Professional Paper 1767, 59 p., accessed June 2018, at https://doi.org/ $10.3133 / \mathrm{pp} 1767$. 

For more information, contact:

Director, New York Water Science Center

U.S. Geological Survey

425 Jordan Road

Troy, NY 12180-8349

dc_ny@usgs.gov

or visit our website at

https://www.usgs.gov/centers/ny-water

Publishing support provided by the

Pembroke Publishing Service Center 


\section{TEF

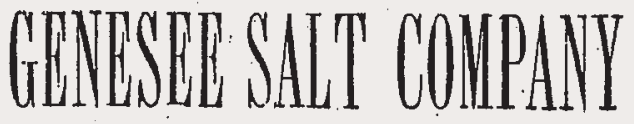

INVITES YOUR ATTHNTION TO ITE

FACTORY FILLED V'ELVET GRAIN (REQISTERED,)

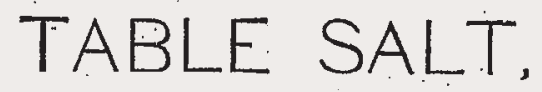

and asks for a trial of its merits on thie following grounds :

1. Genesee Table Salt is the whitest, cleanest, strongest, and purest Table Salt manufactured.

2. It is sifted, not ground.
3. Because of its freedom from lime, chlorides, and other impurities, GENESEE FACTORY FILLED

TABLE SALT will not lump, harden, or gather moisture.

4. It is the best Table and Kitchen Salt made, and gives you the full strength of the UNGROUND NATURAL CRYSTAL.

5. Chemical Analysis proves it to be PURER than any imported salt.

6. It is packed in muslin bags holding $\mathbf{1 4}$, 10, $7,5,3,2$ pounds each.

7. These packages bear the regular Trade Mark of the Company and the Title "VELPET GRAIN," both of which are registered in the U. S. Patent Office. 